\title{
Mid-Year Report: IPC Liaison and Chemistry of Thermal Reconstitution
}

\author{
C. H. Delegard
}

Date Published

May 1995

Prepared for the U.S. Department of Energy Office of Environmental Management, EM-1 Office of Research and Development, EM-53 Efficient Separations and Processing

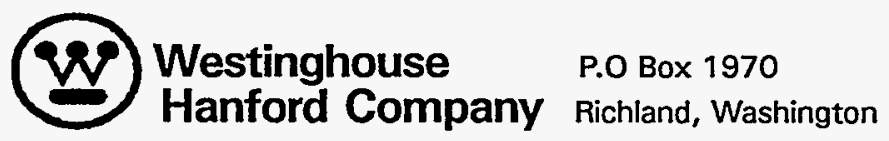

Hanford Operations and Engineering Contractor for the

U.S. Department of Energy under Contract DE-AC06-87RL.10930

\section{Approved for Public Release}




\section{DISCLAIMER}

This report was prepared as an account of work sponsored by an agency of the United States Government. Neither the United States Government nor any agency thereof, nor any of their employees, make any warranty, express or implied, or assumes any legal liability or responsibility for the accuracy, completeness, or usefulness of any information, apparatus, product, or process disclosed, or represents that its use would not infringe privately owned rights. Reference herein to any specific commercial product, process, or service by trade name, trademark, manufacturer, or otherwise does not necessarily constitute or imply its endorsement, recommendation, or favoring by the United States Government or any agency thereof. The views and opinions of authors expressed herein do not necessarily state or reflect those of the United States Government or any agency thereof. 


\section{DISCLAIMER}

Portions of this document may be illegible in electronic image products. Images are produced from the best available original document. 


\section{RELEASE AUTHORIZATION}

Document Number: $\quad$ HHC-SP-1156

Document Title: MID-YEAR REPORT: IPC LIAISON AND CHEMISTRY OF

THERMAL RECONSTITUTION

Release Date: $\quad 5 / 26 / 95$

This document was reviewed following the procedures described in WHC-CM-3-4 and is:

APPROVED FOR PUBLIC RELEASE

WHC Information Release Administration Specialist:

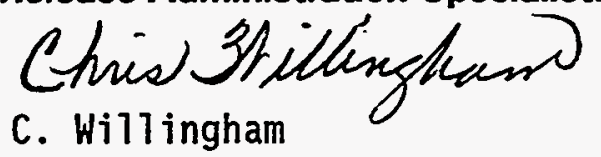

$5 / 26 / 95$ 


\section{MID-YEAR REPORT: IPC LIAISON AND CHEMISTRY OF THERMAL RECONSTITUTION}

\section{EXECUTIVE SUMMARY}

A program of investigation into the chemistry of alkaline Hanford Site tank waste (TTP RLA-3-20-04) is being conducted in FY 1995 at Westinghouse Hanford Company under support from the Efficient Separations and Processing (ESP) Crosscutting Program (EM-53). The investigations have two main subtasks: liaison with the Institute of Physical Chemistry of the Russian Academy of Sciences and further laboratory testing of the chemistry of thermal reconstitution of Hanford Site tank waste.

Progress achieved from 1 October 1994 to 30 April 1995 in the two subtasks is summarized.

\section{Liaison with the Institute of Physical Chemistry}

1. A technical dialogue has been established with the Institute scientists.

2. Editing of a technical literature review on the chemistry of the transuranic elements and technetium in alkaline media written by researchers at the Institute is complete. The report is scheduled for distribution in May 1995.

3. Four tasks from the Institute have been selected for support by the US Department of Energy. Work on three of the four tasks commenced on 1 March 1995 and the initial monthly reports on these tasks show significant progress.

4. Technical information has been supplied to the Institute describing the composition of Hanford Site tank waste.

5. A paper has been prepared for presentation at the Fifth International Conference on Radioactive Waste Management and Environmental Remediation (ICEM), Berlin, Germany, 3-9 September 1995.

\section{Chemistry of Thermal Reconstitution}

1. Tests, using genuine waste from tank 104-S (a REDOX Process sludge), comparing the performance of thermal reconstitution with enhanced sludge washing show markedly improved dissolution of aluminum achieved by the thermal treatment. Other tests are underway for wastes from tanks 101-SY (a complexant concentrate with high chromium concentration) and 102-SY (a high TRU, high chromium, Plutonium Finishing Plant waste). Tests planned for tank 110-U (a mixed aluminum cladding, REDOX Process and Bismuth 
Phosphate Process waste) will not be performed due to budget reallocation to work at the Institute of Physical Chemistry.

2. A reduction/coprecipitation method was tested and shown to remove plutonium, solubilized by thermal treatment, rapidly and efficiently from solution.

3. Technical chemistry support was provided to calciner kinetics tests at the University of Idaho.

4. Tests to determine the speciation of plutonium and neptunium solubilized by thermal treatment show dissolved $\mathrm{Pu}(\mathrm{V})$ and $\mathrm{Np}(\mathrm{V})$ hydroxide complexes are produced. A $\mathrm{Np}(\mathrm{V})$ peroxide complex also was identified.

5. Recently published data on $\mathrm{Pu}$ (IV) carbonate complexation in moderately alkaline ( $\mathrm{pH} 12$ to 13$)$ solution led to reexamination of previous investigations of plutonium complexation in highly alkaline ( 3 to 5 molar $\mathrm{NaOH}$ ) solutions. The comparisons show $\mathrm{Pu}(\mathrm{IV})$ carbonate complexes may also exist in the highly alkaline solution.

6. A public-release technical report on the chemistry of thermal reconstitution was prepared and issued. 
TABLE OF CONTENTS

1.0 INTRODUCTION $\ldots \ldots \ldots \ldots \ldots \ldots \ldots \ldots \ldots \ldots \ldots$

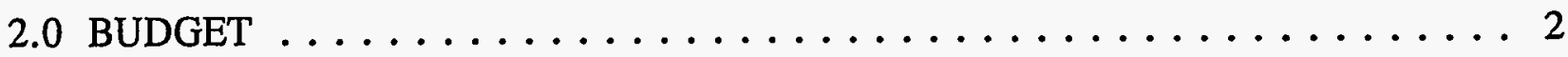

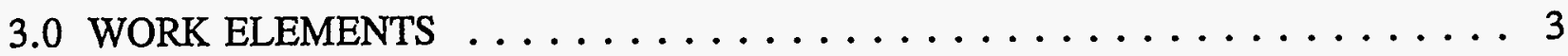

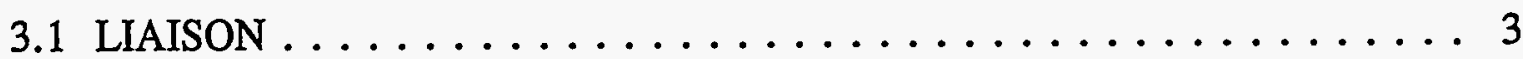

3.2 C/D CHEMISTRY $\ldots \ldots \ldots \ldots \ldots \ldots \ldots \ldots \ldots \ldots \ldots \ldots \ldots$

4.0 MID-YEAR STATUS $\ldots \ldots \ldots \ldots \ldots \ldots \ldots \ldots \ldots \ldots \ldots \ldots \ldots \ldots$

4.1 IPC/RAS LIAISON $\ldots \ldots \ldots \ldots \ldots \ldots \ldots \ldots \ldots \ldots \ldots$

4.1.1 Editing and Publication of the Literature Review . . . . . . 5 5

4.1.2 Task Selection . . . . . . . . . . . . . . 7

4.1.3 Provision of Technical Information $\ldots \ldots \ldots \ldots \ldots \ldots$

4.1.4 Consultation on C/D Chemistry $\ldots \ldots \ldots \ldots \ldots \ldots \ldots$

4.1 .5 Technical Paper . . . . . . . . . . . . . . 10

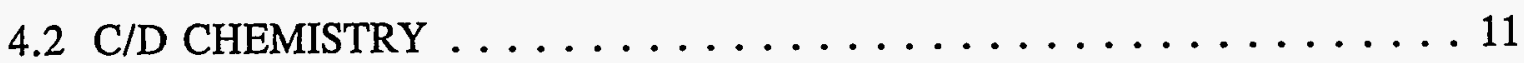

4.2.1 C/D and ESW Comparison Testing . . . . . . . . 12

4.2.1.1 Experimental Materials and Methods ......... 13

4.2.1.2 Results of ESW and C/D Testing for Tank 104-S Waste .. 15

4.2.2 Plutonium Removal from C/D Product Solutions . . . . . . . . . 19 4.2.2.1 Coprecipitation Tests with Tank 102-SY Waste C/D

Solution . . . . . . . . . . . . . . 19

4.2.2.2 Coprecipitation Tests with Neptunium- and Plutonium-

Spiked Simulant . . . . . . . . . . . 21

4.2.3 Work with the University of Idaho Plasma Laboratory . . . . . . 22

4.2.4 Determination of Plutonium and Neptunium Solution Species ... 23

4.2.5 Carbonate Complexes of Plutonium in Alkaline Solution . . . . . 25

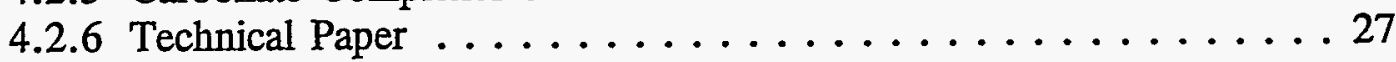

5.0 ACKNOWLEDGEMENTS $\ldots \ldots \ldots \ldots \ldots \ldots \ldots \ldots \ldots \ldots \ldots \ldots \ldots \ldots \ldots$

6.0 REFERENCES $\ldots \ldots \ldots \ldots \ldots \ldots \ldots \ldots \ldots \ldots \ldots \ldots \ldots \ldots \ldots \ldots$ 


\section{WHC-SP-1156}

\subsection{INTRODUCTION}

The task "IPC Liaison and Chemistry of Thermal Reconstitution" is a $\$ 300 \mathrm{~K}$ program being conducted in FY 1995 with U. S. Department of Energy (DOE) Office of Research and Development (EM-53) Efficient Separations and Processing (ESP) Crosscutting Program support under TTP RL4-3-20-04. The Principal Investigator (PI) is Cal Delegard of the Westinghouse Hanford Company (WHC). The task encompasses two subtasks related by their focus on the chemistry of alkaline Hanford Site tank waste:

1. Technical Liaison with the Institute of Physical Chemistry, Russian Academy of Sciences (IPC/RAS), and their program of research into the chemistry of transuranic elements (TRU) and technetium (Tc) in alkaline media.

2. Laboratory investigation of the chemistry of thermal reconstitution (Calcination/Dissolution or $C / D$ ) as an alternative to the present reference Hanford Site tank waste pretreatment flowsheet, Enhanced Sludge Washing (ESW).

This report fulfills the milestones "Provide Progress Report to IP Coordinator," due 1 June 1995, for both subtasks. 


\subsection{BUDGET}

Reallocation of funds to provide more support to the IPC/RAS (specifically, Professor A. K. Pikaev, PI, and his investigations of the role of radiolysis on TRU and Tc chemistry in alkaline media) are currently underway and will decrease the total fiscal year funding from $\$ 300 \mathrm{~K}$ to $\$ 260 \mathrm{~K}$. To free the funds, tests comparing C/D with ESW will be decreased to study three rather than four genuine waste types. As of mid-year, 31 March 1995, funding and spending were on-track and consistent with the decreased budget (Table 2-1).

Table 2-1 Mid-Year Budget Status.

\begin{tabular}{|c|c|c|c|}
\hline & Liaison & C $/ \mathrm{D}$ & Total \\
\hline Budgeted & $\$ 67.4 \mathrm{~K}$ & $\$ 90.1 \mathrm{~K}$ & $\$ 157.5 \mathrm{~K}$ \\
\hline Spent & $\$ 62.6 \mathrm{~K}$ & $\$ 74.7 \mathrm{~K}$ & $\$ 137.3 \mathrm{~K}$ \\
\hline
\end{tabular}




\subsection{WORK ELEMENTS}

Work elements for the liaison and C/D chemistry tasks were stated in the TTP and are described briefly. Additional work elements, not anticipated at the time of drafting the TTP, have since emerged and are also described.

\subsection{LIAISON}

Three work elements for the IPC/RAS liaison were originally listed in the TTP.

1. Edit and publish, in WHC public-release format, the literature review ("Alkaline Chemistry of Transuranium Elements and Technetium and the Treatment of Alkaline Radioactive Wastes") prepared by Professors Peretrukhin, Shilov, and Pikaev.

2. Aid in evaluating and selecting IPC/RAS tasks for DOE support.

3. Provide technical information on the Hanford Site tank waste system to the IPC/RAS.

Additional liaison work elements are:

1. Consult with the IPC/RAS scientists on the anticipated chemistry of actinides in $\mathrm{C} / \mathrm{D}$ processing.

2. Prepare a technical paper for presentation at the Fifth International Conference on Radioactive Waste Management and Environmental Remediation (ICEM), Berlin, Germany, 3-9 September 1995.

\subsection{C/D CHEMISTRY}

The C/D chemistry subtask originally had three work elements defined in the TTP.

1. Conduct $C / D$ and ESW experiments using genuine Hanford Site tank wastes and compare the bulk chemical and radionuclide material balances.

2. Investigate candidate process steps for removing plutonium solubilized by $\mathrm{C} / \mathrm{D}$ treatment of genuine wastes.

3. Support engineering lab tests of calcination conducted, under Tank Waste Remediation System (TWRS, EM-30) funding, at the University of Idaho. 


\section{WHC-SP-1156}

Additional work elements were initiated under the C/D chemistry subtask.

1. Determine plutonium and neptunium solution species produced in C/D processing of simulant wastes.

2. Investigate carbonate complexation of plutonium in highly alkaline solution.

3. Prepare a technical report on $\mathrm{C} / \mathrm{D}$ processing of Hanford Site tank wastes. 


\subsection{MID-YEAR STATUS}

Current fiscal year progress (through 30 April 1995) in pursuit of the tasks underway for TTP RL4-3-20-04 is given.

\subsection{IPC/RAS LIAISON}

The IPC/RAS liaison began in FY 1994 with nominal funding ( $\$ 5 \mathrm{~K})$ to initiate and continue technical discussions with Professor Vladimir F. Peretrukhin of the IPC/RAS. A large portion of the FY 1994 funding was used to bring Professor Peretrukhin to the Hanford Site (from a conference he was attending in San Francisco) in March 1994 for a three day visit and technical discussions. During his visit, he presented a comprehensive assessment of the current state of knowledge of TRU and Tc chemistry in alkaline media in a one-hour seminar to a group of about 80 Hanford Site scientists and engineers. This seminar was a summary of the technical literature review being prepared at the IPC/RAS under sponsorship of the DOE.

The IPC/RAS delivered their technical literature review of the chemistry of TRU and Tc in alkaline media in August 1994. The IPC/RAS had also provided several updated and increasingly detailed lists of proposed areas of investigation of the fundamental and applied chemistry of TRU and Tc in alkaline media for consideration for DOE support beginning in FY 1995.

The initial eleven areas of investigation proposed by the IPC/RAS encompassed 270 person-months of activity. Prioritization of the several proposed tasks began in FY 1994. The DOE International Program goal was to select a mix of IPC/RAS tasks that would require about $\$ 100 \mathrm{~K}$ annual support for the first year (equivalent, without Institute overheads, to about 10 or 15 person-years of effort at the professor and $\mathrm{PhD}$ level) and which would provide the highest immediate value to the Hanford Site and the DOE technical community.

Under the liaison (funded at $\$ 100 \mathrm{~K}$ in FY 1995), dialogue with the IPC/RAS was conducted almost exclusively by FAX between Cal Delegard, PI, and the lead IPC/RAS PI, Professor Peretrukhin. Transmission of documents were through Federal Express, Dr. Tom Albert (of Tom Albert and Associates, the lead in making business and contract arrangements for the DOE with the IPC/RAS) and other visitors to the IPC/RAS, and the occasional visitor from Russia to the US. Postal service in Russia is not reliable and was not used.

\subsubsection{Editing and Publication of the Literature Review}

In August 1994, the IPC/RAS supplied two paper copies of the technical literature review, "Alkaline Chemistry of Transuranium Elements and Technetium and the Treatment of Alkaline Radioactive Wastes" via Professor Gelis of the IPC/RAS to Dr. Albert. The review, which was written in English, was prepared by Professors Vladimir F. Peretrukhin, V. P. Shilov, and Alexei K. Pikaev. The review contained 192 pages, over 300 references, 
7 figures, and 41 tables. Topics addressed in the review were oxidation state thermodynamics, solubilities and speciation, redox reactions, electrochemistry, radiation chemistry, and separations (ion exchange, solvent extraction, coprecipitation) of TRU and Tc in alkaline media.

About 15 photocopies of the text were made and distributed to technical personnel in the DOE community. In consultation with Dr. Jack Watson, the Program Coordinator of EM-53 International Programs, it was decided, and the Russian authors agreed, that the review would be technically edited and published as a DOE contractor (WHC) document.

The paper text was submitted to the Multimedia Services of WHC (Boeing Computer Services), optically scanned, and read into electronic format. The scanning process was hardly perfect, however, mistaking the number 0 with the letter $\mathrm{O}$, for example, and being completely unsuccessful reading superscripts, subscripts, tables, and equations. A multiple iterative sequence of red-line corrections and reviews was performed by the PI and Multimedia Services to resolve these discrepancies.

At the same time, a technical edit of the paper's contents was performed by the PI. Questions arising in the editing were resolved through a FAX dialogue between the US and Russian PIs. Some changes in the punctuation, spelling, and grammar were made, as might be expected. In general, however, the IPC/RAS authors showed outstanding command of the English language and as well as clarity in expressing complicated scientific thoughts.

A number of enhancements were made by the PI and Multimedia Services in preparing the report for issue:

- The figures were redrafted and placed in the rest of the document with the WordPerfect 5.1 electronic format. Casting the entire document in electronic format makes it accessible to an electronic database of reports being prepared by the DOE.

- A more detailed table of contents was prepared. Indexes of tables and figures were added.

- Technical literature citations were made consistent and expanded to include English translations, where available, of reports or books originally published in Russian.

- A table was prepared listing the titles of the Russian language scientific journals cited in the report, a translation of the journal titles, and a listing of the English language versions, if available, of the Russian journals. Significantly, only one reference cited a journal not available in English translation.

- Citations of publications written in English were derived for references cited by their versions in the Russian language. 
- Spellings of Russian author names, transliterated into English, were made consistent with the spellings used in the primary chemical science abstracting journal, Chemical Abstracts. This will aid searching of the technical literature for other papers by the same author.

The edited report was dispatched by Federal Express to the IPC/RAS authors in mid March 1995 for review and comment. Comments and changes to the edited report by the authors were received by FAX on 14 April 1995. Publication and distribution of the final report,

\section{Alkaline Chemistry of Transuranium Elements and Technetium and the} Treatment of Alkaline Radioactive Wastes, V. F. Peretrukhin, V. P. Shilov, and A. K. Pikaev, WHC-EP-0817, Westinghouse Hanford Company, Richland, Washington (1995),

will occur in May 1995.

\subsubsection{Task Selection}

Nine laboratory tasks into the chemistry of the TRU (neptunium, plutonium, americium; $\mathrm{Np}, \mathrm{Pu}$, and $\mathrm{Am}$, respectively) and Tc were proposed by the IPC/RAS for DOE support in March 1994. The proposed tasks, communicated by Professor Peretrukhin during his visit to the Hanford Site, are listed with the requested funding level [in person-months].

1. Determination of hydroxide compound solubility in 1-14 $\mathrm{M} \mathrm{NaOH}$ for $\mathrm{Np}(\mathrm{IV})-(\mathrm{VI}), \mathrm{Pu}(\mathrm{III})-(\mathrm{VI}), \mathrm{Am}(\mathrm{III})-(\mathrm{VI}), \mathrm{Tc}(\mathrm{IV}), \mathrm{Tc}(\mathrm{V})$. [25]

2. Determination of actinide and Tc species in 1-14 M NaOH. [10]

3. Research in the field of actinide and Tc redox reactions and the development of techniques for their stabilization in desired oxidation states in alkaline media. [25]

4. Photochemical and sonochemical reactions of actinides in alkaline media and their use to accelerate precipitated hydroxide dissolution. [20]

5. Radiolysis of actinides and Tc in alkaline media. [20]

6. Coprecipitation of actinides (IV), (V), and (VI) from alkaline solutions. [25]

7. Extraction of actinides and Tc from alkaline media; search for new extractants. [20]

8. Sorption of actinides and Tc from alkaline media. [50] 


\section{WHC-SP-1156}

9. Electrochemical methods in alkaline radwaste treatment; actinide and $\mathrm{Tc}$ isolation and nitrate, nitrite, and organic compound destruction. [25]

Two proposals later were added for consideration.

10. Destruction of organic impurities in waste. [25]

11. Separation of liquid and solid phases in the system 0.1-4 M

$\mathrm{NaOH} / \mathrm{Fe}(\mathrm{OH})_{3}$ by filtration with metallic spiral filters. [25]

Over the period May to October 1994, more explicit descriptions of the proposed tasks, as well as references to relevant publications and curriculum vitae of the lead investigators, were provided to the liaison PI by the IPC/RAS. The eleventh proposal, related to spiral filters, later was withdrawn when alternative support was obtained from Battelle, Pacific Northwest Laboratories (PNL).

The proposed tasks were broadly classified as fundamental and applied chemistry studies. Thus, tasks related to solubility, speciation, redox reactions, and radiation chemistry address fundamental chemistry. The applied chemistry tasks relate primarily to separations or processing (filtration, coprecipitation, extraction, electrochemistry, sorption, organic destruction).

On the basis of the limited funding (about $\$ 100 \mathrm{~K}$ ) available from the International Program, a selection of the tasks had to be made. Consideration was given to the alternatives of supporting a few tasks at full scope or a greater number of tasks at reduced scope. In discussions with Dr. Watson, full support for three or four tasks was selected as the best use of the limited resources.

The decision also was made (in consultation with Dr. Watson and Mr. John Swanson of PNL) initially to favor support of the fundamental chemistry over the applied chemistry. Strong interest in the coprecipitation task was shown, however, since solid-liquid phase separations are the irreducible minimum processes to achieve the low/high-level waste separation in envisioned Hanford Site tank waste pretreatment.

In the end, four tasks were selected for study: solubility, redox reactions, radiation chemistry, and coprecipitation. Outlines of the tasks' scopes, the task PIs and requested support follow.

1. Determination of solubilities of hydroxo compounds of $\mathrm{Np}(\mathrm{IV})$-(VI), $\mathrm{Pu}$ (III)-(VI), Am(III)-(VI), and Tc(IV)-(V) in 0.5-14 M NaOH. PI: V. F. Peretrukhin. 25 person-months.

- Determine the solubility of $N p(I V)$ and $P u(I V)$ in reducing media

- Determine the solubility of $\mathrm{Np}(\mathrm{VI})$ and $\mathrm{Pu}(\mathrm{VI})$

- Determine the solubility of $\mathrm{Na}_{2} \mathrm{AnO}_{2}(\mathrm{OH})_{3}(\mathrm{An}=\mathrm{Np}, \mathrm{Pu}, \mathrm{Am})$

- Determine $\operatorname{Am}(O H)_{3}$ solubility (exclude radiolysis products) 
- Study effects of complexing agents (carbonate, phosphate, fluoride, chelating agents, and hydroxycarboxylate anions) on solubilities

- Synthesize, and study solubilities of, $\mathrm{Tc}(\mathrm{IV})$ and $\mathrm{Tc}(\mathrm{V})$ hydroxides.

2. Research in An and Tc redox reactions and reagents in alkali. PI: V. P. Shilov. 25 person-montbs.

- Study reactions of $\mathrm{Np}(\mathrm{IV})$ and $\mathrm{Pu}(\mathrm{IV})$ with ozone, atmospheric oxygen, permanganate, persulfate, ferricyanide, ferrate, chromate, hypochlorite, and hypobromite

- Study $\mathrm{Np}(\mathrm{V})$ and $\mathrm{Pu}(\mathrm{V})$ oxidation by atmospheric oxygen in the presence of complexing agents

- Study products of reaction of Tc with hydrazine, hydroxylamine, and sulfite

- Investigate kinetics of $\mathrm{Np}(\mathrm{V}), \mathrm{Pu}(\mathrm{V})$, and $\mathrm{Am}(\mathrm{V})$ reduction by hydrazine, hydroxylamine, and sulfite

- Study Tc(IV)-(V) oxidation by ozone, atmospheric oxygen, manganate, hypochlorite, and hypobromite.

3. Radiolysis of actinides and technetium in alkaline media. PI: A. K. Pikaev. 25 person-months.

- Study radiolysis of $\mathrm{Np}(\mathrm{V})$-(VI) and $\mathrm{Pu}(\mathrm{V})-(\mathrm{VI})$ in alkaline and carbonate media and the effects of nitrite, nitrate, and EDTA

- Study gamma radiolysis oxidation of Tc(IV)-(V) and reduction of $\mathrm{Tc}$ (VII) as functions of solution concentrations.

4. Determination of coprecipitating agents for An(IV)-(VI). PI: N. N. Krot. 25 person-months.

- Identify reagents (in addition to permanganate, manganate, ferrate, chromate) as prospective sources of coprecipitants

- Study methods to induce coprecipitation reactions

- Investigate $\mathrm{Np}(\mathrm{V})-(\mathrm{VI})$ and $\mathrm{Pu}(\mathrm{V})-(\mathrm{VI})$ behavior with coprecipitants.

The liaison PI informed the IPC/RAS of this selection in November 1994. However, business arrangements (contracts, avenues for funding, support for the Institute facilities) remained to be made by Dr. Albert. Subsequent analysis by the DOE of the funding available revealed that only three of the four tasks could be supported. The radiation chemistry task of Professor Pikaev was deleted as a result and Professor Pikaev was notified of this decision by Dr. Albert in February 1995.

Contract negotiations went forward for the remaining three tasks and work at the IPC/RAS commenced on 1 March 1995 by Professors Peretrukhin, Shilov, and Krot. Monthly reports for March 1995 for these three tasks have been received; significant progress for all tasks was described. A request also was received from the three researchers for funding to purchase a liquid scintillation counter (estimated cost $\$ 60$ to 100K) to perform radionuclide concentration analyses. 
In the mean time, reallocation of $\$ 40 \mathrm{~K}$ of funding from the present TTP (i.e., Liaison and Chemistry of Thermal Reconstitution) to the support of the radiation chemistry task was agreed by Dr. Watson and the PI. The $\$ 300 \mathrm{~K}$ total funds initially allocated for the TTP thus will decrease to $\$ 260 \mathrm{~K}$. Professor Pikaev was notified in April 1995 by DOE that support for his task was reinstated. Work on this task is expected to commence immediately following conclusion of the contract arrangements.

\subsubsection{Provision of Technical Information}

Provision of Hanford Site tank waste technical information continued. Two reports on the chemistry of C/D were sent to the IPC/RAS. These reports, in addition to describing $\mathrm{C} / \mathrm{D}$ experiments and results, contain general and tank-specific waste compositions that are useful to understanding the existing waste chemistry. The reports delivered are:

1. Chemistry of Application of Calcination/Dissolution to the Hanford Tank

Waste Inventory, C. H. Delegard, T. D. Elcan, and B. E. Hey, WHC-EP-

0766, Westinghouse Hanford Company, Richland, Washington (1994).

\section{Chemistry of Proposed Calcination/Dissolution Processing of Hanford Site}

Tank Wastes, C. H. Delegard, WHC-EP-0832, Westinghouse Hanford

Company, Richland, Washington (1995).

\subsubsection{Consultation on C/D Chemistry}

Advantage was taken of the knowledge and experience of the IPC/RAS researchers to discuss actinide behavior in the C/D processing of plutonium- and neptunium-spiked simulant wastes. The IPC/RAS (specifically, Prof. Peretrukhin) evaluated some C/D test results sent by FAX in December 1994. Professor Peretrukhin provided valuable insights into the formation of (V) and (VI) dissolved species and the effects of peroxide complexation in a return FAX message received in January 1995. The C/D results will be described in greater detail in a subsequent section of this report.

\subsubsection{Technical Paper}

A technical paper on the liaison and the results of the IPC/RAS work funded by the DOE was prepared for presentation at the meeting, "Fifth International Conference on Radioactive Waste Management and Environmental Remediation," to be held in Berlin, Germany, on 3-9 September 1995. The conference is sponsored by the American Society of Mechanical Engineers, the American Nuclear Society, the DOE, the Kerntechnische Gesellschaft, and the Battelle Memorial Institute.

The paper was prepared at the request of Dr. Teresa Fryberger of the DOE, EM-53. Professor Peretrukhin has reviewed the paper and agreed to participate in the conference and present the paper. The paper has been issued as a WHC document (Peretrukhin and Delegard 1995) in anticipation of its publication in the book of proceedings. 


\subsection{C/D CHEMISTRY}

Studies of the technology (chemistry and engineering) of $C / D$ have been conducted at WHC at various levels of both EM-30 and EM-50 support since FY 1992. Following the Tri-Party Agreement decision in FY 1994 to focus on enhanced sludge washing (ESW) as the reference pretreatment flowsheet and markedly reduce investigation of other pretreatment alternatives, only limited support of C/D was provided by EM-30 via TWRS in FY 1995.

TWRS support of C/D ultimately was limited in FY 1995 to a continuation of engineering lab scale non-transferred plasma torch $(50 \mathrm{~kW})$ calcination tests begun at the University of Idaho in FY 1994. A small level of support for chemistry studies of C/D also was granted by TWRS primarily to aid the University of Idaho tests.

In contrast, EM-50 saw merit in the continuing pursuit of alternative pretreatment technologies should the reference ESW technology prove inadequate to provide efficient separations of low level and high level wastes (LLW and HLW, respectively). On this basis, EM-50, under the present TTP, granted a $\$ 200 \mathrm{~K}$ level of support to the continued studies of C/D chemistry.

The focus of the chemistry work was the direct comparison, in lab scale studies using genuine waste, of C/D with ESW. Determination of bulk chemical and radionuclide material balances (solution and residual solid phases) in these tests would allow direct evaluation of the performance of the reference ESW and competing C/D technologies in solubilizing key bulk constituents (primarily aluminum, chromium, and phosphate) and radioactive but chemically trace constituents of Hanford Site tank wastes.

Tests conducted in FYs 1993 and 1994 with genuine tank wastes showed plutonium was dissolved by $\mathrm{C} / \mathrm{D}$ processing. The dissolution causes the undesired partitioning of a portion of the plutonium, an HLW component, to the LLW fraction. It was postulated that plutonium dissolved by oxidation to more soluble (V) or (VI) oxidation states from the sparingly soluble $\mathrm{Pu}^{(\mathrm{IV})} \mathrm{O}_{2} \cdot \mathrm{xH}_{2} \mathrm{O}$ solid phase most likely present in the waste. In the earlier work, the plutonium behavior was compared with the demonstrated behavior of manganese, a bulk constituent in the waste, because it undergoes a similar oxidative dissolution in C/D processing

$$
\mathrm{MnO}_{2}+[\mathrm{O}]+2 \mathrm{OH}^{-} \rightarrow \mathrm{MnO}_{4}{ }^{2-}+\mathrm{H}_{2} \mathrm{O} \text {. }
$$

These observations suggested use of chemical reduction and coprecipitation (which essentially reverses the oxidative dissolution reactions of plutonium and manganese) as a method to remove solubilized plutonium from solution. The coprecipitation was expected to be particularly effective due to the high sorptive capacity of the product manganese dioxide $\left(\mathrm{MnO}_{2}\right)$. To explore this possibility, a work element to determine the feasibility of the. reduction/coprecipitation approach was included in the TTP.

A final TTP work element was included to support the lab-scale plasma calciner tests being conducted by Professor Pat Taylor of the Department of Metallurgical and Mining 
Engineering, College of Mines, at the University of Idaho. The work being performed by Professor Taylor and colleagues was supported by TWRS, EM-30.

\subsubsection{C/D and ESW Comparison Testing}

The applicability of C/D as a Hanford Site tank waste pretreatment process must be demonstrated to offer advantages in performance and/or cost when compared with the reference pretreatment flowsheet. The step originally conceived for pretreatment of tank waste was simple water washing followed by solid-liquid separation to segregate the highlevel insoluble residue from the low-level solution fraction (after removal of ${ }^{137} \mathrm{Cs}$, and possibly ${ }^{90} \mathrm{Sr}$ and ${ }^{99} \mathrm{Tc}$ as well). The high-level fraction (and separated ${ }^{137} \mathrm{Cs}$ ) would be vitrified for storage in the HLW repository while the LLW fraction would be immobilized as grout. Glass later was chosen as the LLW form.

Certain bulk chemical components in the insoluble waste residue (primarily aluminum, chromium, and phosphate) contribute significantly to the volume of vitrified HLW slated for expensive packaging and deep geological repository storage. With this in mind, ESW was proposed as a possible treatment that would be more successful than simple water washing in dissolving the aluminum, chromium, and phosphate sludge components.

The ESW pretreatment is a sequence of washes, alkaline leaches, and rinses that is intended to:

1. dissolve water-soluble sodium salts (e.g., $\mathrm{NaNO}_{3}, \mathrm{NaNO}_{2}, \mathrm{Na}_{2} \mathrm{CO}_{3}, \mathrm{Na}_{3} \mathrm{PO}_{4}$ )

2. dissolve amphoteric aluminum and chromium hydroxides as their soluble hydroxide-complexed anions:

$$
\begin{aligned}
& \mathrm{Al}(\mathrm{OH})_{3}(\mathrm{~s})+\mathrm{OH}^{-} \rightarrow \mathrm{Al}(\mathrm{OH})_{4}^{-} \\
& \text {[bayerite or gibbsite solid phase] } \\
& \mathrm{AlOOH}(\mathrm{s})+\mathrm{OH}^{-}+\mathrm{H}_{2} \mathrm{O} \rightarrow \mathrm{Al}(\mathrm{OH})_{4}^{-} \\
& \text {[böhmite solid phase] } \\
& \mathrm{Cr}(\mathrm{OH})_{3}(\mathrm{~s})+\mathrm{OH}^{-} \rightarrow \mathrm{Cr}(\mathrm{OH})_{4}^{-}
\end{aligned}
$$

3. dissolve phosphates by hydroxide metathesis:

$$
(\mathrm{Fe}, \mathrm{Bi}) \mathrm{PO}_{4}(\mathrm{~s})+3 \mathrm{OH}^{-} \rightarrow(\mathrm{Fe}, \mathrm{Bi})(\mathrm{OH})_{3}(\mathrm{~s})+\mathrm{PO}_{4}{ }^{3-} .
$$

It is noted that the ESW leach conditions are similar to, but considerably milder than, the conditions the aluminum industry uses to dissolve aluminum values from bauxitic ores containing the same gibbsite, bayerite, and böhmite aluminum-bearing solid phases as found in tank sludges (Hudson 1987). Gibbsite and böhmite phases are especially prominent in REDOX process sludge. 
As shown in the above reactions, the dissolution of $\mathrm{Cr}(\mathrm{OH})_{3}$ by alkaline treatment is analogous to that exhibited by $\mathrm{Al}(\mathrm{OH})_{3}$; i.e., it is based the amphoterism of the metal ion. Quantification of the $\mathrm{Cr}$ (III) hydrolysis reaction is underway at PNL (Felmy et al. 1994).

In comparative water wash and C/D tests conducted with genuine wastes in FY 1993 and 1994, dissolutions of aluminum, chromium, and phosphate were invariably higher by C/D and often approached 100\% dissolution (Delegard et al. 1994a, and Delegard 1995). With the introduction of ESW as the reference pretreatment approach, similar tests, using genuine tank wastes, must be conducted to compare the performances of C/D and ESW.

\subsubsection{Experimental Materials and Methods}

\section{C/D Tests:}

The C/D experimental technique has been developed in tests performed over the past two years (Delegard et al. 1994a and Delegard 1995). Briefly, weighed aliquots of genuine waste sludge materials are dried in an alumina crucible at about $120^{\circ} \mathrm{C}$ for several hours to remove solution water, heated at $300^{\circ} \mathrm{C}$ for 20 minutes to remove bound (hydrate) water, and finally transferred directly to an $850^{\circ} \mathrm{C}$ furnace for 20 minutes' calcination. This stepwise drying eliminates rapid boil-up and dispersal of the radioactive materials and thus improves operational safety and achievement of material balance.

The calcine then is cooled and dissolved, in three contacts, with "Q" (purified) water. The initial water contact is conducted directly in the crucible. The solution and insoluble materials from the first water contact are transferred to a centrifuge cone. The product slurry is centrifuged, the supernatant solution decanted, and the solution weight and volume determined. Two subsequent $\mathrm{Q}$ water wash contacts (with centrifugation and decantation) are made of the residual solids and the two separate solution fractions are composited, their volumes determined, and weighed. The residue is dried at $100^{\circ} \mathrm{C}$ and weighed. The solutions and residues are analyzed for chemical and radionuclide concentrations in the Analytical Laboratories of 222-S at WHC and a material balance calculated.

For many sludges, which are deficient in salts (nitrate, nitrite, hydroxide) to supply the fluxing sodium hydroxide required for $\mathrm{C} / \mathrm{D}$ reactions, an additional source of flux is required. If $\mathrm{C} / \mathrm{D}$ were applied to the Hanford Site tank waste sludges, the source of fluxing agent would be the abundant tank salt cake wastes. Earlier C/D lab tests either used waste from tank 101-SY or used reagent sodium nitrate $\left(\mathrm{NaNO}_{3}\right)$ to supply the flux. Hanford Site salt cake waste has been shown to be predominantly $\mathrm{NaNO}_{3}$.

Samples of genuine salt cake are not currently available in the laboratory; therefore, reagent $\mathrm{NaNO}_{3}$ now is used in $\mathrm{C} / \mathrm{D}$ tests where additional fluxing agent is required. The amounts of $\mathrm{NaNO}_{3}$ added are calculated to be sufficient to exceed the $\mathrm{NaOH}$ requirements of the genuine waste aliquot at least two-fold on the basis of fusion reactions to form soluble sodium salts. The reaction of aluminum hydroxide with sodium hydroxide to form the water-soluble sodium aluminate salt is one such fusion reaction: 
WHC-SP-1156

$$
2 \mathrm{NaOH}+2 \mathrm{Al}(\mathrm{OH})_{3} \rightarrow 2 \mathrm{NaAlO}_{2}+3 \mathrm{H}_{2} \mathrm{O}(\mathrm{g}) .
$$

ESW Tests:

The ESW test procedure was adopted from a laboratory protocol provided by Dr. Gregg Lumetta of PNL. The steps used in the ESW tests are described by the following general laboratory instructions.

1. Weigh a 5 gram genuine waste aliquot accurately into a tare weighed capped $50-\mathrm{mL}$ polypropylene centrifuge cone.

2. Add $15 \mathrm{~mL}$ of $0.01 \mathrm{M} \mathrm{NaOH} / 0.01 \mathrm{M} \mathrm{NaNO}_{2}$ wash solution to the waste aliquot.

3. Heat the cone and contents to $100^{\circ} \mathrm{C}$ for two hours.

4. Remove the cone/contents from the oven, cool, centrifuge, and decant the liquid into a tare-weighed container. Reweigh to determine solution weight.

5. Repeat steps 2 to 4 for two more wash contacts (i.e., three total). Composite the three washes for analysis.

6. Contact the residue with $15 \mathrm{~mL} 3 \mathrm{M} \mathrm{NaOH}$ leach solution. Heat at $100^{\circ} \mathrm{C}$ for five hours.

7. Remove the cone/contents from the oven, cool, centrifuge, and decant the liquid into a tare-weighed container. Reweigh to determine solution weight.

8. Repeat steps 6 and 7 for another contact. Composite the two collected leach solutions for analysis.

9. Rinse the residual solids with $15 \mathrm{~mL}$ water (no heating or extended contact time required). Centrifuge, decant, and repeat the rinse. Composite the two rinses for analysis in a tare weighed container and reweigh.

10. Dry the residual solids at $100^{\circ} \mathrm{C}$ and record the final weight.

As in the C/D tests, the solutions and residues produced by the ESW tests were analyzed for chemical and radionuclide concentrations in the Analytical Laboratories of 222-S at WHC and material balances calculated.

Materials:

The sludges used in the C/D and ESW tests to date this fiscal year are from tank 104$\mathrm{S}$, a REDOX Process waste with high amounts of aluminum hydroxide phases, and 101-SY, a complexed concentrate waste containing a relatively high concentration of chromium in the 
sludge phase. A waste remaining to be tested this fiscal year is from tank 102-SY, a chromium rich waste having high TRU concentrations from the Plutonium Finishing Plant (PFP). A sludge from tank 110-U containing mixed REDOX, aluminum cladding, and Bismuth Phosphate Process wastes was to be tested but reallocation of $\$ 40 \mathrm{~K}$ to support Professor Pikaev at the IPC/RAS will not permit completion of this work (chemical and radionuclide analytical costs for the tank 110 -U work were estimated to be $\$ 35 \mathrm{~K}$ ).

The amounts of waste materials and added chemicals $\left(\mathrm{NaNO}_{2}\right.$ and $\mathrm{NaOH}$ used in the ESW leachants and $\mathrm{NaNO}_{3}$ used as salt cake simulant for $\mathrm{C} / \mathrm{D}$ ) for the tests with the tank 104-S waste (the only tests for which data are complete) and the tank 101-SY and 102-SY wastes are summarized in Table 4-1. The relative amounts of added sodium used in the tests also are compared. As shown in Table 4-1, the tank 104-S ESW test used over twice as much sodium, per unit waste, than the C/D test. For the 101-SY or 102-SY C/D tests, no added $\mathrm{NaNO}_{3}$ was used whereas the prescribed amounts of $\mathrm{NaNO}_{2}$ and $\mathrm{NaOH}$ were used for the ESW tests. It is important to recognize that the sodium required for ESW originates from additions of fresh purchased $\mathrm{NaNO}_{2}$ and $\mathrm{NaOH}$. The added sodium in these salts ultimately becomes contaminated waste and contributes directly to the vitrified LLW waste bulk (LLW glass bulk is sodium limited). In contrast, the C/D sodium requirements are met using salt cake already present in the waste tanks and thus would add nothing to the LLW waste bulk.

Table 4-1 Materials Used in ESW and C/D Tests.

\begin{tabular}{||c|c|c|c|c||}
\hline \multirow{4}{*}{$\begin{array}{c}\text { Tank } \\
\text { Waste } \\
\text { Source }\end{array}$} & \multicolumn{4}{|c|}{ Weights of Materials Used in Tests } \\
\cline { 2 - 5 } & ESW & \multicolumn{2}{c||}{$\mathrm{C} / \mathrm{D}$} \\
\hline $104-\mathrm{S}$ & $4.999 \mathrm{~g} / 0.031 \mathrm{~g} / 3.618 \mathrm{~g}$ & 0.42 & $10.011 \mathrm{~g} / 7.150 \mathrm{~g}$ & 0.19 \\
\cline { 2 - 5 } & waste $/ \mathrm{NaNO}_{2} / \mathrm{NaOH}$ & $\begin{array}{c}\mathrm{g} \mathrm{Na} / \\
\mathrm{g} \text { waste }\end{array}$ & waste $/ \mathrm{NaNO}_{3}$ & $\begin{array}{c}\mathrm{g} ~ \mathrm{Na} / \\
\mathrm{g} \text { waste }\end{array}$ \\
\hline $101-\mathrm{SY}$ & $5.083 \mathrm{~g} / 0.031 \mathrm{~g} / 3.618 \mathrm{~g}$ & 0.41 & $5.98 \mathrm{~g} / 0 \mathrm{~g}^{1}$ & 0 \\
\hline $102-\mathrm{SY}$ & $5.290 \mathrm{~g} / 0.031 \mathrm{~g} / 3.618 \mathrm{~g}$ & 0.40 & $18.086 \mathrm{~g} / 0 \mathrm{~g}^{2}$ & 0 \\
\hline
\end{tabular}

${ }^{1}$ Delegard et al. 1994.

${ }^{2}$ Delegard 1995.

The compositions of the wastes used in the ESW and C/D comparison tests (from tanks 104-S, 101-SY, and 102-SY) are given in Table 4-2.

\subsubsection{Results of ESW and C/D Testing for Tank 104-S Waste}

ESW and C/D test results for tank 104-S waste may be compared based on the quantities of bulk chemical components and the trace radionuclides dissolved by the respective processing alternatives. 
Table 4-2 Compositions of Hanford Site Tank Wastes Used in the C/D and ESW Tests.

\begin{tabular}{||c|c|c|c||}
\hline \multirow{2}{*}{ Component } & \multicolumn{3}{|c|}{ Concentration (wt\%) } \\
\cline { 2 - 4 } & $104-\mathrm{S}$ & $101-\mathrm{SY}^{1}$ & $102-\mathrm{SY}^{2}$ \\
\hline $\mathrm{Al}$ & 6.78 & 3.8 & 3.04 \\
\hline $\mathrm{Ca}$ & 0.049 & 0.027 & 0.15 \\
\hline $\mathrm{Cr}$ & 0.157 & 0.48 & 1.15 \\
\hline $\mathrm{Fe}$ & 0.177 & 0.028 & 0.82 \\
\hline $\mathrm{K}$ & - & 0.38 & 0.18 \\
\hline $\mathrm{Mn}$ & 0.080 & $0.0068^{*}$ & 0.26 \\
\hline $\mathrm{Na}$ & 7.00 & 24.4 & 8.13 \\
\hline $\mathrm{Ni}$ & 0.49 & 0.018 & 0.22 \\
\hline $\mathrm{Si}$ & 0.21 & $0.046^{*}$ & 0.13 \\
\hline $\mathrm{U}$ & 0.25 & 0.0074 & 0.14 \\
\hline $\mathrm{Cl}$ & 0.20 & 0.93 & 0.18 \\
\hline $\mathrm{F}^{-}$ & $<0.0007$ & 0.04 & 0.056 \\
\hline $\mathrm{NO}_{2}^{-}$ & 1.90 & 12.4 & 2.44 \\
\hline $\mathrm{NO}_{3}^{-}$ & 14.2 & 13.8 & 5.71 \\
\hline $\mathrm{PO}_{4}{ }^{3-}$ & $<0.007$ & 0.76 & 1.26 \\
\hline $\mathrm{SO}_{4}{ }^{2-}$ & 0.091 & 0.47 & 4.17 \\
\hline $\mathrm{CO}_{3}^{2-}$ & 1.39 & 3.72 & 1.96 \\
\hline $\mathrm{OH}^{-2}$ & 0.94 & 2.92 & 0.96 \\
\hline $\mathrm{TOC}^{-2}$ & 0.76 & 1.81 & 0.54 \\
\hline $\mathrm{H}_{2} \mathrm{O}$ & 60.5 & $23.8^{*}$ & 62.5 \\
\hline \hline $\mathrm{Nuclide}^{2}$ & \multicolumn{2}{|c|}{ Concentration $(\mu \mathrm{Ci} / \mathrm{g})$} \\
\hline${ }^{90} \mathrm{Sr}^{29}$ & 154 & 25 & 85.8 \\
\hline${ }^{99} \mathrm{Tc}$ & 0.012 & 0.24 & 0.10 \\
\hline${ }^{137} \mathrm{Cs}$ & 38.5 & 396 & 51.9 \\
\hline${ }^{237} \mathrm{~Np}^{239,240} \mathrm{Pu}$ & $<0.013$ & 0.000032 & 0.00086 \\
\hline${ }^{241} \mathrm{Am}$ & 0.199 & 0.0076 & 4.38 \\
\hline & & 0.12 & 14.9 \\
\hline
\end{tabular}

${ }^{1}$ Based on Herting et al. 1992 and corrected for water content; * value from current analysis.

2 From Delegard 1995.

The dissolutions of bulk chemical constituents by the two processes are compared in Figure 1. The amounts dissolved are displayed next to the amounts present in the initial waste mixtures (i.e., mixtures which include the $\mathrm{NaNO}_{2} / \mathrm{NaOH}$ processing chemicals used in ESW and the $\mathrm{NaNO}_{3}$ salt cake simulant used in C/D).

Both ESW and C/D dissolved about $99 \%$ of the sodium. This behavior would be expected except for wastes which contain significant concentrations of both aluminum and silicon. In such a case, insoluble sodium aluminosilicates $\left(\mathrm{NaAlSiO}_{4}\right.$; e.g., sodalite, 
WHC-SP-1156

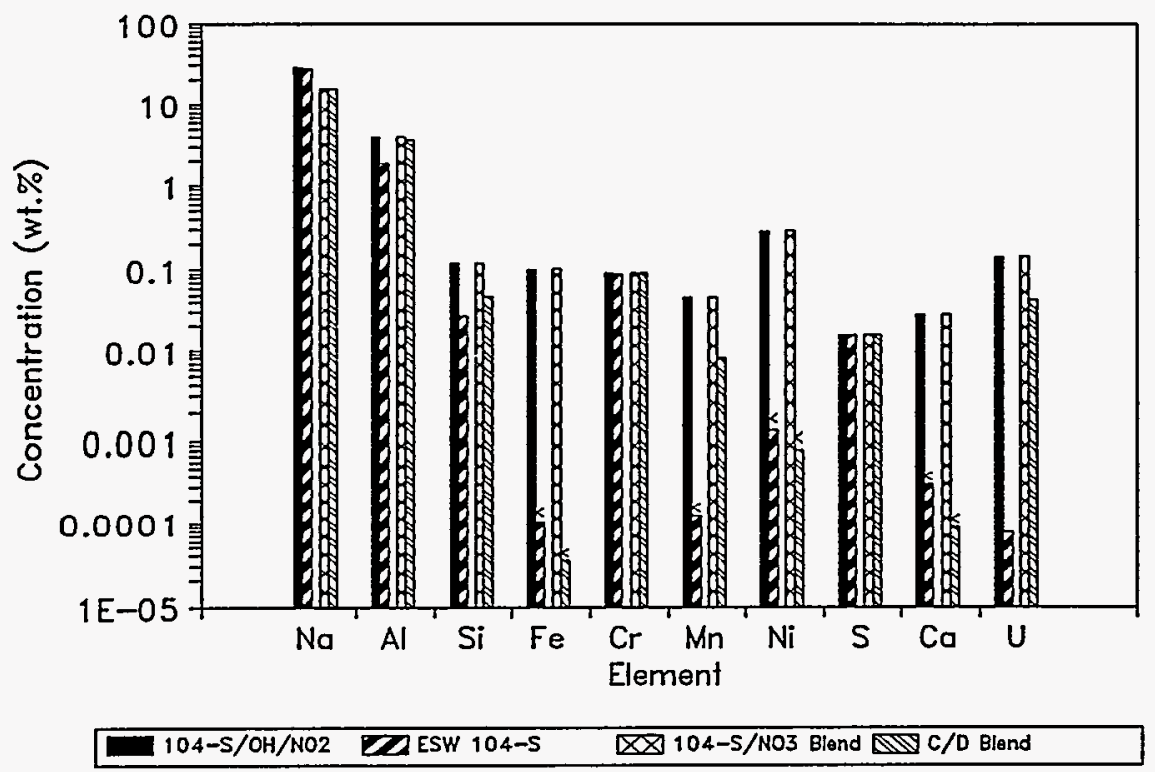

Figure 1. Dissolution of Bulk Waste Constituents in ESW and C/D Processing of Tank 104-S Waste

cancrinite) form in alkaline solution and sodium is precipitated. Because the 104-S waste contains high concentrations of aluminum but relatively minor silicon concentrations, no $\mathrm{NaAlSiO}_{4}$ should form.

Aluminum dissolutions were markedly different for the ESW and C/D processes. C/D dissolved about $91 \%$ of the aluminum in the 104-S waste; ESW only dissolved $47 \%$. $\mathrm{X}$-ray diffractometry of the 104-S starting material revealed the presence of the difficultlysoluble phase böhmite $(\mathrm{AlOOH})$ but not the less refractory gibbsite $\left[\mathrm{Al}(\mathrm{OH})_{3}\right]$. When böhmite is encountered in aluminum-bearing ore, the aluminum industry uses severe (200 to $230^{\circ} \mathrm{C}$ ) digestion conditions. This is 90 to $100^{\circ} \mathrm{C}$ higher than used to dissolve gibbsitic ores (Hudson 1987) and 100 to $120^{\circ} \mathrm{C}$ higher than used in the present ESW tests. For the tank 104-S waste, C/D processing gives aluminum dissolution distinctly superior to that of ESW.

Both approaches dissolved essentially all the chromium (about $97 \%$ dissolved by ESW and $>99.9 \%$ dissolved by $\mathrm{C} / \mathrm{D}$ ). Inspection of the ESW data revealed that chromium dissolution was essentially complete in the initial dilute $\mathrm{NaNO}_{2} / \mathrm{NaOH}$ wash steps. Analyses of the original tank 104-S waste also showed the contained chromium to be readily water soluble and reporting to solution as chromate $\left(\mathrm{CrO}_{4}{ }^{2}\right)$. Thus, because the chromium in this tank 104-S waste sample was present only as $\mathrm{CrO}_{4}{ }^{2}$, the $\mathrm{Cr}(\mathrm{OH})_{3}$ hydrolysis reaction could not be demonstrated for ESW.

Essentially all the sulfur (sulfate) was dissolved by both ESW and C/D. Because the tank 104-S waste contained insufficient phosphorus to detect, phosphate dissolution behavior could not be determined. Silicon and manganese dissolutions were higher for $C / D$ than for ESW. About $40 \%$ of the silicon dissolved by C/D vs. $22 \%$ by ESW. Manganese dissolution 
was about $18 \%$ by $\mathrm{C} / \mathrm{D}$ and less than $0.3 \%$ by ESW. Dissolutions of iron, nickel, and calcium were negligible by both C/D and ESW.

The dissolutions of radioactive components achieved by ESW and C/D processing of tank 104-S sludge are presented in Figure 2. As expected for wastes containing no complexing agents (e.g., EDTA), neither process dissolved significant amounts of ${ }^{241} \mathrm{Am}$ (less than $1 \%$ dissolved in both cases) or ${ }^{90} \mathrm{Sr}$ (less than $0.3 \%$ dissolved). In contrast, and as expected, both processes dissolved most of the ${ }^{137} \mathrm{Cs}$ (about $96 \%$ by ESW and $98 \%$ by C/D). Technetium-99 dissolution was about $64 \%$ for ESW and about $20 \%$ by C/D. The behavior of ${ }^{99} \mathrm{Tc}$ is erratic and may be related to the low concentrations in the tank 104-S waste thus making accurate analyses difficult. Tests with wastes having higher concentrations of ${ }^{99} \mathrm{Tc}$ (e.g. tanks 101-SY and 102-SY) will be reported at the end of the fiscal year.

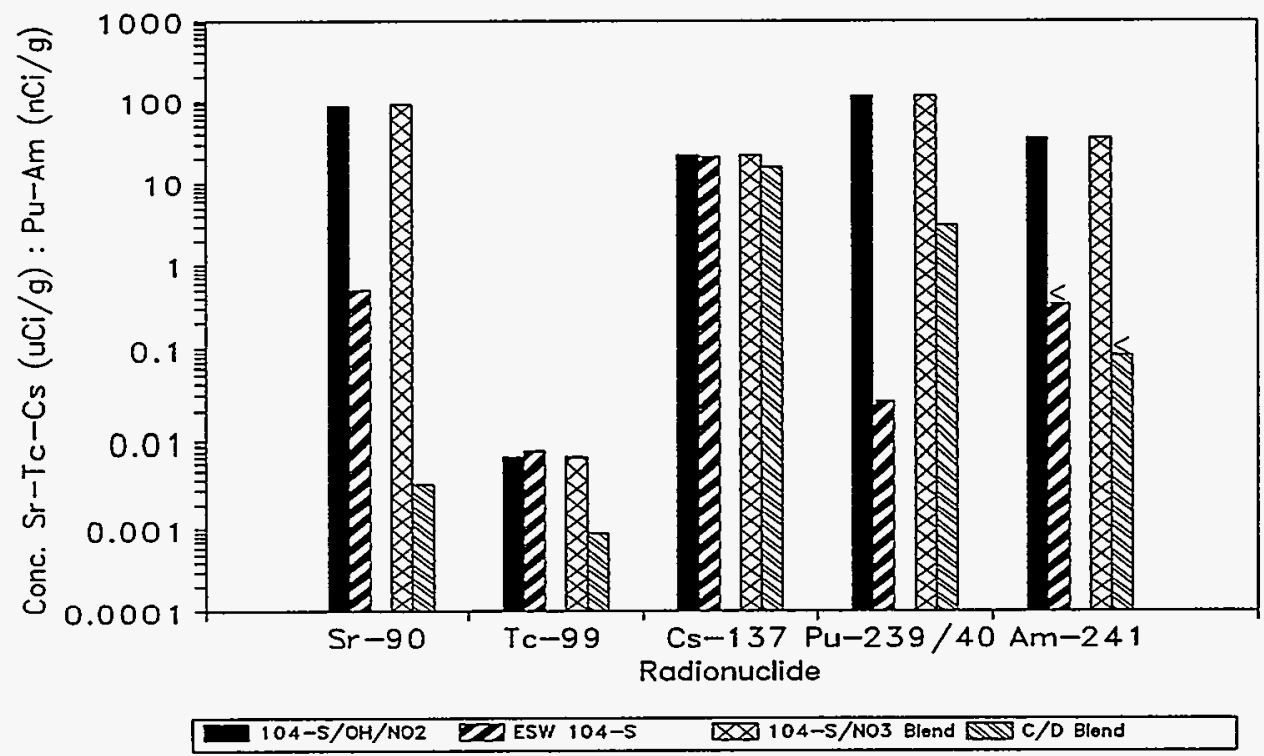

Figure 2. Dissolution of Radioactive Components in ESW and C/D Processing of Tank 104-S Waste

Because the concentrations of ${ }^{237} \mathrm{~Np}$ in the tank 104-S waste were below the analytical detection limits, the behavior of this important TRU isotope could not be determined. In contrast, the concentrations of uranium present in the waste were relatively high (about 0.6 weight percent, on a dry weight basis). The ESW process dissolved only about $0.05 \%$ of the uranium (see Figure 1); the C/D process, almost $30 \%$.

The ${ }^{239,240} \mathrm{Pu}$ dissolved in ESW processing is less than $0.02 \%$. In contrast, the ${ }^{239,240} \mathrm{Pu}$ dissolved by $\mathrm{C} / \mathrm{D}$ is about $3 \%$. The dissolution of plutonium by $\mathrm{C} / \mathrm{D}$ processing has been noted in earlier studies of C/D (Delegard et al. 1994a and Delegard 1995) and was postulated to be due to oxidative dissolution, in analogy with the behavior of manganese. Experiments to confirm this hypothesis and to determine methods to remove the solubilized plutonium were conducted in the current fiscal year. 


\subsubsection{Plutonium Removal from C/D Product Solutions}

As shown in the previous section for tank 104-S waste, and discussed in earlier C/D tests, manganese and plutonium dissolution behaviors are similar in $\mathrm{C} / \mathrm{D}$ processing. The similar behaviors are thought to be due to oxidation to form soluble anions $\left(\mathrm{MnO}_{4}{ }^{2-}\right.$, and $\mathrm{PuO}_{2}(\mathrm{OH})_{4}{ }^{2-}$ or $\mathrm{PuO}_{2}(\mathrm{OH})_{4}{ }^{3-}$, respectively). The dissolution of plutonium, and its reporting to the LLW solution phase, in pretreatment processing is not desired. If plutonium reports to the dissolved LLW stream, a secondary step must be used to remove plutonium from solution.

Reduction of the manganate to form insoluble manganese dioxide $\left(\mathrm{MnO}_{2}\right)$, the corollary reduction of the solubilized plutonate $[\mathrm{Pu}(\mathrm{V})$ or $\mathrm{Pu}(\mathrm{VI})]$ to form plutonium dioxide $\left(\mathrm{PuO}_{2}\right)$, and the coprecipitation of the product oxides offer a promising approach to remove the solubilized plutonium from the LLW stream. Experiments were conducted to test reduction/coprecipitation with C/D product solutions originating from genuine tank 102-SY waste and plutonium- and neptunium-spiked Hanford Site tank composite simulant waste. The reductants tested, hydroxylamine hydrochloride $\left(\mathrm{NH}_{2} \mathrm{OH} \cdot \mathrm{HCl}\right)$ and hydrogen peroxide $\left(\mathrm{H}_{2} \mathrm{O}_{2}\right)$, are volatile at glass forming temperatures and thus have the advantage of adding no bulk to the vitrified waste form.

\subsubsection{Coprecipitation Tests with Tank 102-SY Waste C/D Solution}

Reduction and coprecipitation experiments were conducted with three separate product solutions from C/D testing of tank 102-SY waste. Though the solutions had been stored in the laboratory for up to 100 days following the $C / D$ experiments, the continuing presence of dissolved manganese was evident by the intense green solution coloration due to manganate $\left(\mathrm{MnO}_{4}{ }^{2-}\right)$ for two of the solutions and maroon due to permanganate $\left(\mathrm{MnO}_{4}^{-}\right)$for the remaining solution.

Each of the three stored solutions were centrifuged and the supernatant solutions withdrawn. Aliquots of the solutions were analyzed to determine bulk metal concentrations and concentrations of dissolved radionuclides. One molar solutions of the hydroxylamine and peroxide reductants were prepared from reagent chemicals and $\mathrm{Q}$ water.

Five $\mathrm{mL}$ aliquots of the clarified solutions were drawn. In separate tests, the reductants were added dropwise (about $0.05 \mathrm{~mL}$ per drop) to the $5 \mathrm{~mL}$ test aliquots, the solutions agitated, and the solution's appearances noted.

Reactions in all cases were rapid and vivid. Introduction of only one drop of reductant was sufficient in all cases to cause solution color to change instantly from dark green (due to manganate) or maroon (due to permanganate in the solution having lower hydroxide concentration), to brown, and then to bright yellow. After a few seconds, as the brown color was supplanted by the yellow, small dark brown solids formed. These observations are consistent with the precipitation of brown manganese(IV) dioxide reduced from the soluble manganate or permanganate. The residual yellow solution color was due to chromate $\left(\mathrm{CrO}_{4}^{2-}\right)$. 
Addition of the peroxide resulted in some bubbling in the solution; hydroxylamine addition gave a small amount of white precipitate at the point of introduction. The precipitate [probably $\mathrm{Al}(\mathrm{OH})_{3}$ precipitated by the acidic hydrochloride salt] dissolved rapidly with mixing.

The suspensions were centrifuged and the supernatant solutions analyzed for bulk metal and radionuclide concentrations. The results of the analyses for one of the manganate test solutions are shown in Figures 3 and 4. Similar test results were obtained for the other two test solutions.

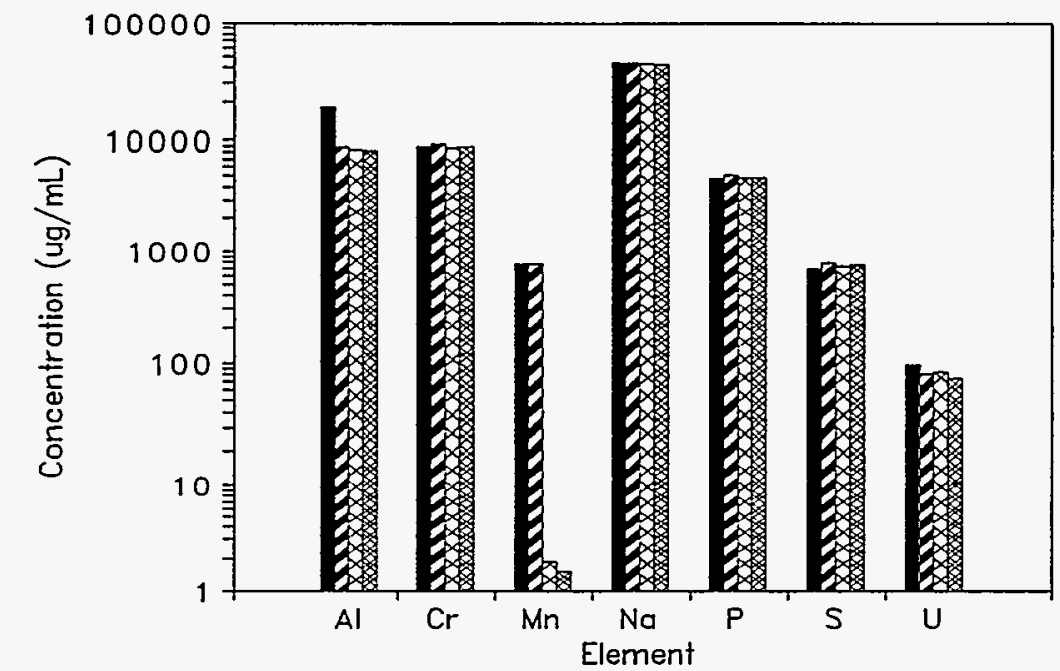

Orig. $(t=0) \bigotimes t=100 d \quad \mathrm{H} 2 \mathrm{O} 2$

Figure 3. Concentration of Bulk Waste Constituents in Tank 102-SY C/D Solution Before and After Treatment with Peroxide and Hydroxylamine

The test data indicate that both hydroxylamine and peroxide removed both manganese (Figure 3) and plutonium (Figure 4) from solution. Concentration reductions for both metals with each reagent were about a factor of three hundred. Significantly, chromium solution concentrations did not decrease by reduction of chromate to the poorly soluble $\mathrm{Cr}(\mathrm{OH})_{3}$. Thus, the beneficial effect of chromium solubilization by $\mathrm{C} / \mathrm{D}$ was not negated by the plutonium/manganese reductive coprecipitation. Some coprecipitation of ${ }^{90} \mathrm{Sr}$ also occurred. Concentrations of other metals or radionuclides were apparently not affected by the use of the reductants.

Results from these initial scoping tests for coprecipitation indicate that plutonium solubilized by C/D may be rapidly and efficiently removed from solution. However, analytical results for neptunium were near the analytical detection limit and thus were difficult to interpret. Further tests using neptunium-spiked simulant waste therefore were performed to elucidate the behavior of neptunium. 


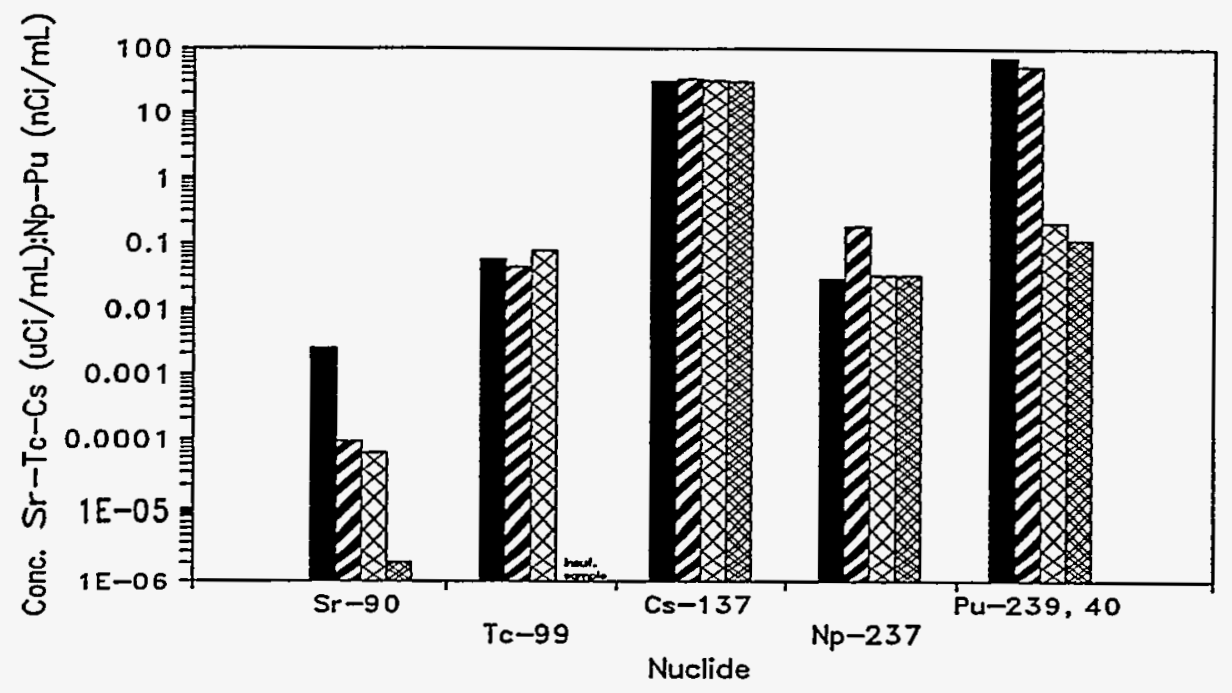

Orig. $(t=0) \cong \mathrm{H}=100 \mathrm{~d}$

Figure 4. Concentrations of Radionuclides in Tank 102-SY C/D Solution Before and After Treatments with Peroxide and Hydroxylamine

\subsubsection{Coprecipitation Tests with Neptunium- and Plutonium-Spiked Simulant}

The behavior of neptunium in C/D processing has been difficult to determine due its low concentration in Hanford Site tank wastes tested. Some solubilization of neptunium by $\mathrm{C} / \mathrm{D}$ is expected based on the similarity of its chemistry to that of plutonium. If anything, neptunium is easier to oxidize in alkaline solution than plutonium (Peretrukhin et al. 1995) and therefore would be more susceptible to oxidative dissolution by $\mathrm{C} / \mathrm{D}$ processing.

The composition of a comprehensive Hanford Site tank waste simulant containing the most prevalent 27 chemical components of the tank waste (over 99.99 mole percent) has been described (Delegard et al. 1994a). Nitric acid solutions of plutonium(IV) and neptunium(V) spike were added to an aliquot of the comprehensive simulant and the spiked simulant processed by C/D.

The $\mathrm{C} / \mathrm{D}$ product solution was separated for analysis and a $5 \mathrm{~mL}$ aliquot of the clarified solution treated with $3 \mathrm{M}$ hydroxylamine hydrochloride. Upon addition of a drop of the hydroxylamine, the color changed immediately from blue-green to yellow. However, no precipitate appeared even after 30 minutes. The treated solution was allowed to stand about 80 hours after which a fine brown precipitate appeared. The original $\mathrm{C} / \mathrm{D}$ product and the hydroxylamine-treated supernatant solutions were analyzed.

Approximately equal concentrations (about $0.004 \mathrm{~g} / \mathrm{L}$ or $1.8 \times 10^{-5} \mathrm{M}$ ) of plutonium and neptunium were found in the $\mathrm{C} / \mathrm{D}$ product solution. The equal concentrations give evidence for similar solubility-limiting phases for these two neighboring actinides. 
The results of the solution analyses before and after hydroxylamine treatment show manganese and plutonium solution concentrations dropped about a factor of thirty by treatment with hydroxylamine; neptunium concentrations dropped about a factor of three (Figure 5). Chromium solution concentrations also decreased about $20 \%$ and lead decreased about $30 \%$. The slowness of the precipitation reaction may be due to the low initial concentration of the dissolved manganese or to complexation by excess hydroxylamine. Further tests must be conducted to determine the cause of the slowness of the precipitation reaction and to determine if heating improves the rate of reduction/coprecipitation.

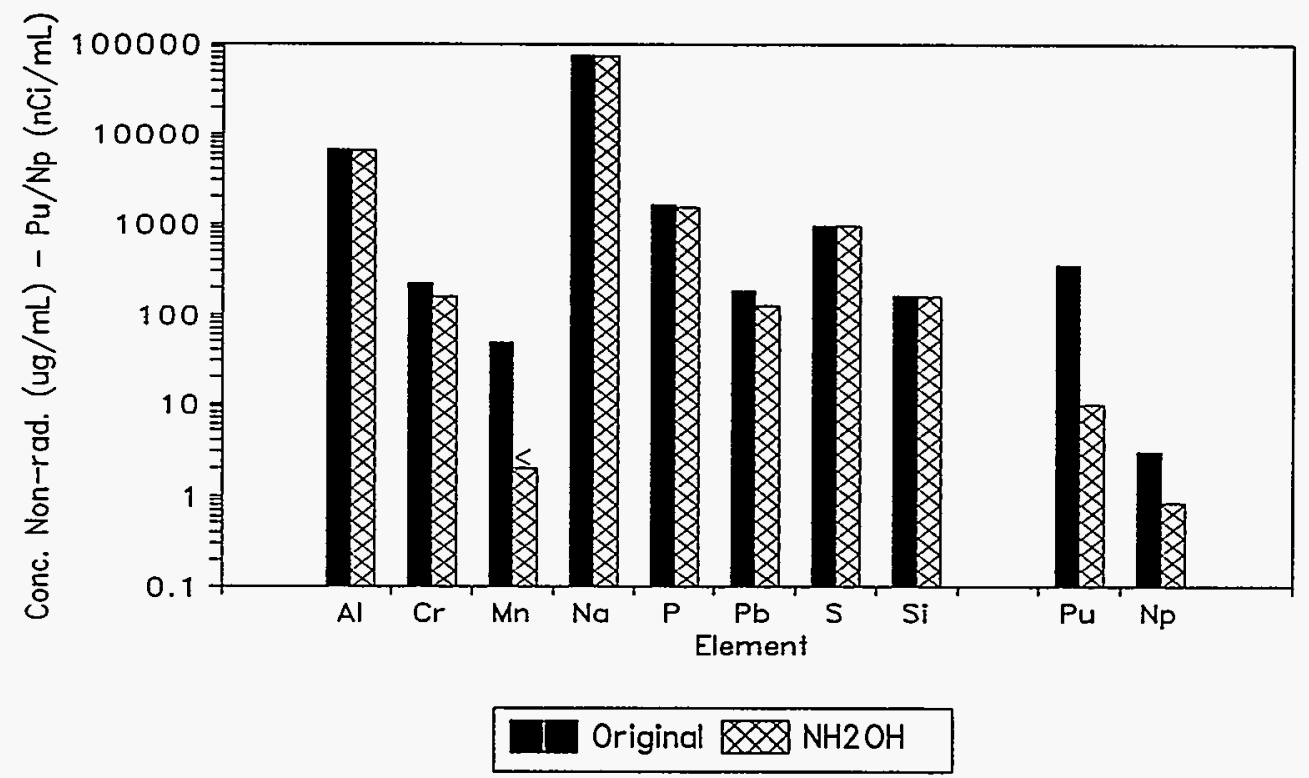

Figure 5. Concentrations of Bulk Constituents and Radionuclides in Simulant C/D Solution Before and After Treatment with Hydroxylamine

\subsubsection{Work with the University of Idaho Plasma Laboratory}

Engineering lab scale calcination studies of simulated Hanford Site tank wastes were conducted at the University of Idaho (UI) under the direction of Professor Patrick Taylor. Mr. R. S. Goheen of PNL coordinated the UI work. Results of the UI studies have recently been reported (Goheen et al. 1995).

In the UI tests, the kinetics of the fundamental calcination chemical reactions; nitrate/nitrite decomposition, conversion of $\mathrm{Al}(\mathrm{OH})_{3}$ to $\mathrm{NaAlO}_{2}$, oxidation of $\mathrm{Cr}(\mathrm{OH})_{3}$ to form $\mathrm{CrO}_{4}{ }^{2-}$, and organic carbon destruction; were investigated as functions of calciner power and residence time. A $50-\mathrm{kW}$ non-transferred plasma torch was used to provide the rapid heating required for the tests. The non-transferred torch means the plasma arc does not pass through the material to be heated. Instead, gas heated by the plasma arc is used to transfer heat to the waste. This heat-transfer method is identical to that used in earlier pilot-scale calcination tests of tank 101-SY simulant waste conducted in November 1992 and November 1993 at the Westinghouse Science and Technology Center in Waltz Mill, Pennsylvania (Delegard et al. 1994b). 
The PI provided information to the researchers at the UI on compositions of candidate Hanford Site waste simulants, analytical methods, and goals of C/D processing. The PI also visited the laboratory at the UI campus for discussions with Professor Taylor and his staff, reviewed the interim and final reports, and arranged a technical seminar by the PI (on C/D chemistry) and Professor Taylor (on the plasma reactor results) at the Hanford Site for TWRS program managers and engineers. TWRS funding of the plasma calciner tests was terminated on 31 January 1995 with the publication of the test results (Goheen et al. 1995).

\subsubsection{Determination of Plutonium and Neptunium Solution Species}

The solubilization of plutonium occurring in the C/D processing of genuine tank waste has been ascribed to the formation of more soluble anionic oxidized species. Similar solubilities of plutonium and neptunium, found in the C/D processing of spiked simulant wastes, implies that similar chemistries exist for these two neighboring actinides. With this basis, tests were performed to identify plutonium and neptunium solution species created in the $\mathrm{C} / \mathrm{D}$ of simulant waste materials.

Because spectrophotometric techniques are non-invasive and do not disturb the solution chemistry, they are ideally suited to identify dissolved species. Separate plutoniumand neptunium-spiked simulant wastes were prepared, subjected to $C / D$ processing, and the product solution analyzed spectrophotometrically (using a Perkin-Elmer Lambda 9 spectrophotometer; lower detection limit of about 0.0005 absorbance units for a $1-\mathrm{cm}$ cell).

To permit observation of the suspected actinide species, which have low concentrations and low molar absorptivities, simulant wastes having no strongly absorbing chromophores were prepared. Thus, a Hanford Site tank waste composite sludge was created according to the published recipe (Delegard et al. 1994a) but from which iron, chromium, nickel, manganese, and bismuth had been omitted. A surrogate waste simulating the composition of tank 102-SY waste and including added $\mathrm{NaNO}_{3}$ (but with iron, chromium, and manganese omitted) also was created. The compositions of the two simulant waste types are given in Table 4-3.

The absorption spectra of the C/D product solutions were gathered for both simulant waste types. The neptunium-spiked tank waste composite sludge had a dissolved neptunium concentration of $0.034 \mathrm{~g} / \mathrm{L}\left(1.4 \times 10^{-4} \mathrm{M}\right)$ and showed a spectrum matching a published spectrum of $\mathrm{Np}(\mathrm{V})$ (Cohen and Fried 1969). The corresponding plutonium-spiked material had a dissolved plutonium concentration of about $0.028 \mathrm{~g} / \mathrm{L}\left(1.2 \times 10^{-4} \mathrm{M}\right)$. The spectrum was less distinct but resembled a published spectrum of $\mathrm{Pu}(\mathrm{V})$ (Bourges 1972).

A non-spiked sample of the tank $102-\mathrm{SY} / \mathrm{NaNO}_{3}$ simulant also underwent $\mathrm{C} / \mathrm{D}$ processing. Colorless bubbles were observed in the non-spiked C/D product solution. The neptunium-spiked 102-SY/NaNO ${ }_{3} \mathrm{C} / \mathrm{D}$ product solution had about $0.26 \mathrm{~g} / \mathrm{L}$ dissolved . neptunium. The solution was colored like tea and had an intense absorption in the spectrum below about $700 \mathrm{~nm}$ wavelength. Over the next several days, the solution color faded and the characteristic absorption due to $\mathrm{Np}(\mathrm{V})$ emerged. A quantity of white precipitate also appeared in the sample vial. 
WHC-SP-1156

Table 4-3 Compositions of Waste Simulants Used in Speciation Tests

\begin{tabular}{||c|c|c||}
\hline \multirow{2}{*}{ Constituent } & \multicolumn{2}{|c|}{ Concentration (moles/kg) } \\
\cline { 2 - 3 } & Composite Simulant & $\begin{array}{c}\text { Tank 102-SY Simulant } \\
\text { with added NaNO }\end{array}$ \\
\hline $\mathrm{Al}$ & 0.52 & 0.58 \\
\hline $\mathrm{B}$ & 0.00074 & - \\
\hline $\mathrm{Ca}$ & 0.011 & 0.023 \\
\hline $\mathrm{Ce}$ & 0.0053 & - \\
\hline $\mathrm{K}$ & 0.073 & 0.038 \\
\hline $\mathrm{Mg}$ & 0.00069 & -- \\
\hline $\mathrm{Na}$ & 8.91 & 5.66 \\
\hline $\mathrm{Pb}$ & 0.0067 & -- \\
\hline $\mathrm{Si}$ & 0.056 & 0.026 \\
\hline $\mathrm{Sr}^{2}$ & 0.0013 & - \\
\hline $\mathrm{Cl}^{-}$ & 0.038 & 0.037 \\
\hline $\mathrm{F}^{-}$ & 0.18 & 0.018 \\
\hline $\mathrm{NO}_{2}{ }^{-}$ & 0.65 & 0.38 \\
\hline $\mathrm{NO}_{3}{ }^{-}$ & 5.34 & 3.69 \\
\hline $\mathrm{PO}_{4}{ }^{3-}$ & 0.29 & 0.085 \\
\hline $\mathrm{SO}_{4}{ }^{2-}$ & 0.065 & 0.21 \\
\hline $\mathrm{CO}_{3}{ }^{2-}$ & 0.14 & 0.28 \\
\hline $\mathrm{OH}^{-}$ & 1.4 & 0.55 \\
\hline $\mathrm{TOC}^{*}$ & 0.20 & 0.36 \\
\hline $\mathrm{H}_{2} \mathrm{O}$ & 10.9 & 26.2 \\
\hline & & \\
\hline
\end{tabular}

- Added as acetate.

Based on the bubbling observed in the non-spiked C/D solution and the intense absorption in the lower wavelengths of the neptunium-spiked C/D solution, peroxide complexes of neptunium were suspected. To confirm this, a drop of $1 \mathrm{M} \mathrm{H}_{2} \mathrm{O}_{2}$ was added directly into the spectrophotometric cuvette containing about $3 \mathrm{~mL}$ of the clarified $\mathrm{Np}(\mathrm{V})$ solution. The solution immediately changed to the original tea color with a spectrum matching, except for intensity, the original spectrum. Addition of $100 \mu \mathrm{L}$ of $1 \mathrm{M} \mathrm{H}_{2} \mathrm{O}_{2}$ to the $10 \mathrm{~mL}$ sample containing the neptunium C/D product almost instantly produced the original dark tea color, dissolved the previously observed white precipitate, and gave the original spectrum. The assignment of the tea-colored neptunium spectrum to a $\mathrm{Np}(\mathrm{V})$ 
peroxide complex was corroborated by spectra and other experimental results found in a published report (Musikas 1976).

The plutonium-spiked tank $102-\mathrm{SY}_{\mathrm{NaNO}} \mathrm{Na}_{3}$ simulant gave a disșolved plutonium concentration of $0.009 \mathrm{~g} / \mathrm{L}$. No readily identifiable spectrum was observed. The work of Musikas (1976) indicates that both plutonium(VI) and (V) in alkaline solution form peroxide complexes of only fleeting existence and are rapidly reduced to form $\mathrm{Pu}(\mathrm{IV})$ precipitates.

The speciation data, and the coprecipitation test data reported in section 4.2.2, substantiate the use of chemical reductants, such as peroxide or hydroxylamine, to effect reduction and (co)precipitation of plutonium. The coprecipitation of neptunium is more difficult and complicated by the formation of relatively stable peroxide complexes. In analogy with the well-known reactions of peroxide with actinides in acid media, the peroxide complexes may be destroyed readily by heating. Further investigation of the use of peroxide in the treatment of Hanford Site waste sludges seems warranted.

\subsubsection{Carbonate Complexes of Plutonium in Alkaline Solution}

Furhter quantitative evidence of the formation of carbonate complexes of $\mathrm{Pu}(\mathrm{IV})$ in alkaline solution has recently been presented in the technical literature (Yamaguchi et al. 1994). The evidence consists of enhanced solution concentration of plutonium as carbonate or bicarbonate concentrations increase.

In the cited experiments, plutonium valence was controlled to the (IV) state by use of $\mathrm{NaNO}_{2}$. Tests showed the solid phase contained no carbonate and on this basis, the solid phase $\mathrm{PuO}_{2} \cdot \mathrm{xH}_{2} \mathrm{O}$ was inferred. No spectrophotometry was performed to identify the valence of the dissolved plutonium species. However, the plutonium in the clarified (filtered, at 450 $\mathrm{nm}$ and $3 \mathrm{~nm}$ pore size) solutions was identified as being in the (IV) state by TTA (thenoyltrifluoroacetone) extraction.

Plutonium solution concentration was found to increase in the presence of carbonate and bicarbonate and the plutonium concentration to be proportional to the square of the carbonate or bicarbonate concentration. Two regimes of increasing plutonium concentration were identified: in the region $\mathrm{pH} 9.4$ to 10.1 (where bicarbonate, $\mathrm{HCO}_{3}^{-}$, is predominant) and in the region $\mathrm{pH} 12$ to 13 (where carbonate, $\mathrm{CO}_{3}^{2-}$, is predominant).

On the basis of the $\mathrm{pH}$ dependencies and the observed dependencies of the plutonium solution concentration on (bi)carbonate concentration, two reactions were proposed:

$$
\mathrm{PuO}_{2} \cdot \mathrm{xH}_{2} \mathrm{O}+2 \mathrm{HCO}_{3}^{-} \rightleftarrows \mathrm{Pu}(\mathrm{OH})_{2}\left(\mathrm{CO}_{3}\right)_{2}{ }^{2-}+\mathrm{xH}_{2} \mathrm{O}
$$

in bicarbonate ( $\mathrm{pH} 9.4$ to 10.1$) ; \log \mathrm{K}=-2.7 \pm 0.5$; and

$$
\mathrm{PuO}_{2} \cdot \mathrm{xH}_{2} \mathrm{O}+2 \mathrm{CO}_{3}^{2-} \rightleftarrows \mathrm{Pu}(\mathrm{OH})_{4}\left(\mathrm{CO}_{3}\right)_{2}{ }^{4-}+(\mathrm{x}-2) \mathrm{H}_{2} \mathrm{O}
$$

in carbonate (pH 12 to 13$) ; \log \mathrm{K}=-4.98 \pm 0.31$. 


\section{WHC-SP-1156}

Thus, the solubility of the plutonium solid phase $\left(\mathrm{PuO}_{2} \cdot \mathrm{xH}_{2} \mathrm{O}\right)$ was found to increase in proportion to the square of the bicarbonate or carbonate concentrations, consistent with equations (1) and (2), respectively.

The solubility of $\mathrm{PuO}_{2} \cdot \mathrm{xH}_{2} \mathrm{O}$ in the system $\mathrm{NaOH} / \mathrm{Na}_{2} \mathrm{CO}_{3}$ has been reported (Delegard 1985). Because $\mathrm{Pu}(\mathrm{V})$ species had been observed in concentrated $\mathrm{NaOH}$ solutions, the observed solubility in $\mathrm{NaOH} / \mathrm{Na}_{2} \mathrm{CO}_{3}$ was modelled on the basis of the following net reaction involving $\mathrm{Pu}(\mathrm{V})$ :

$$
\mathrm{PuO}_{2} \cdot \mathrm{xH}_{2} \mathrm{O}+4 \mathrm{OH}^{-}+2 \mathrm{CO}_{3}^{2-} \rightleftarrows \mathrm{PuO}_{2}(\mathrm{OH})_{4}\left(\mathrm{CO}_{3}\right)_{2}{ }^{7-}+\mathrm{x} \mathrm{H}_{2} \mathrm{O}+\mathrm{e}^{-}
$$

Reaction (3) is a combination of two reactions:

$$
\mathrm{PuO}_{2} \cdot \mathrm{xH}_{2} \mathrm{O}+4 \mathrm{OH}^{-} \rightleftarrows \mathrm{PuO}_{2}(\mathrm{OH})_{4}{ }^{3-}+\mathrm{x} \mathrm{H}_{2} \mathrm{O}+\mathrm{e}^{-}
$$

$\log \mathrm{K}=-8.93 \pm 0.16 ;$ and

$$
\mathrm{PuO}_{2}(\mathrm{OH})_{4}^{3-}+2 \mathrm{CO}_{3}^{2-} \rightleftarrows \mathrm{PuO}_{2}(\mathrm{OH})_{4}\left(\mathrm{CO}_{3}\right)_{2}{ }^{7-}
$$

$\log \mathrm{K}=1.13 \pm 0.20$

Reaction (4) was observed in pure concentrated (1 to $15 \mathrm{M}$ ) $\mathrm{NaOH}$ aqueous systems. The solid phase (poorly crystalline $\mathrm{PuO}_{2}$ ) was identified by X-ray diffraction and the solution species was identified as $\mathrm{Pu}(\mathrm{V})$ by spectrophotometric techniques. Reaction (5) was suggested by the enhanced solubility shown when large concentrations of $\mathrm{Na}_{2} \mathrm{CO}_{3}(0.25$ to $1.06 \mathrm{M}$ ) were included in 2.90 to $4.94 \mathrm{M} \mathrm{NaOH}$ solutions. No spectrophotometric or other check of the valence of the dissolved plutonium species was performed for the carbonate experiments. On the basis of the experiments in $\mathrm{NaOH}$ solution, $\mathrm{Pu}(\mathrm{V})$ species were assumed in the $\mathrm{NaOH} / \mathrm{Na}_{2} \mathrm{CO}_{3}$ solutions.

The existence of the proposed mixed hydroxide/carbonate complex described in reactions (3) and (5) is unlikely, however, because of the large negative charge (-7) on the $\mathrm{PuO}_{2}{ }^{+}$central species and because $\mathrm{PuO}_{2}{ }^{+}$has the lowest tendency towards complexation in aqueous media of any plutonium valence.

On the basis of the reported research (Yamaguchi et al. 1994), the original experimental data (Delegard 1985) were re-examined. The enhanced solubility of plutonium observed in the presence of carbonate was first calculated as the difference between the total measured plutonium solution concentration and the concentration expected solely due to reaction (4).

As reported, the solubility changes as a function of time (Delegard 1985). Therefore, the solubility due to reaction (4) in the pure $\mathrm{NaOH}$ system was calculated based on the data taken at 153 days' equilibration. This equilibration time closely matches the 156 day equilibration time allowed for the $\mathrm{NaOH} / \mathrm{Na}_{2} \mathrm{CO}_{3}$ system. Using data taken from Table A-1 of Delegard (1985), the plutonium solution concentration due to the $\mathrm{Pu}(\mathrm{V})$ hydroxide 
complex was calculated. The calculated solubility due to reaction (4) can be described very accurately $\left(R^{2}=0.996\right)$ by the function:

$$
\log [\mathrm{Pu}]=1.997 \log (\mathrm{NaOH})-7.543
$$

where [ ] indicates molal concentrations and ( ) indicates chemical activities.

The data summarized in Table 4-4 are derived from data in Table A-6 of Delegard (1985). The contribution of the $\mathrm{Pu}(\mathrm{V})$ hydroxide complex (designated $[\mathrm{PuOH}]$ in Table 4-4) to the total solution concentration (designated [Pu]) was determined by equation (6). The amount of plutonium solution concentration ascribed to the carbonate complex (i.e., $\left[\mathrm{PuCO}_{3}\right]$ ) was calculated as the difference between the total concentration and the concentration due to the hydroxide complex:

$$
\left[\mathrm{PuCO}_{3}\right]=[\mathrm{Pu}]_{t}-[\mathrm{PuOH}]
$$

The calculated plutonium carbonate complex concentration can be plotted versus the carbonate chemical activity $\left(\mathrm{a}_{\mathrm{Na}_{2} \mathrm{CO} 3}\right)$; the slope of the plot should be proportional to the ligand:metal $\left(\mathrm{CO}_{3}^{2-}: \mathrm{Pu}\right)$ ratio. Such a plot for the data derived from Delegard (1985) is shown in the Figure 6. Also given in Figure 6 are the data derived from Yamaguchi et al. (1994). In this case, where total ionic strength was limited to 0.1 molal (m), the molar (M) concentrations of plutonium was assumed to be equal to its molal concentration and the carbonate molar concentration was assumed to be equal to its activity.

As shown in the Figure 6, the effect of carbonate on the plutonium solubility observed in the data derived from Delegard (1985) is consistent with the effect carbonate has on plutonium solubility in the reported $\mathrm{pH} 12$ and 13 data (Yamaguchi et al. 1994). The data also are consistent with a 2:1 ratio in the postulated $\mathrm{CO}_{3}^{2-}: \mathrm{Pu}(\mathrm{IV})$ complex. The coincidence of these results and the satisfactory explanation provided by Yamaguchi et al. (1994) of the carbonate complexation reactions suggest that a similar mechanism and complex is responsible for the $\mathrm{NaOH} / \mathrm{Na}_{2} \mathrm{CO}_{3}$ system. Further confirmation tests, based on spectrophotometric verification of $\mathrm{Pu}(\mathrm{IV})$ in aqueous $\mathrm{NaOH} / \mathrm{Na}_{2} \mathrm{CO}_{3}$ solutions, are planned.

\subsubsection{Technical Paper}

An external-release document on lab studies of $\mathrm{C} / \mathrm{D}$ processing of genuine Hanford Site tank wastes from tanks 104-T and 111-T (from the Bismuth Phosphate Process) and tank 102-SY (from the Plutonium Finishing Plant) was prepared and issued in January 1995 (Delegard 1995). The document also compared the new results with results from earlier studies of the C/D of tank 101-SY (a complexant concentrate), tank 104-S (a REDOX Process sludge), and tank 107-BX (another Bismuth Phosphate Process waste). 


\section{WHC-SP-1156}

Table 4-4. Experimental and Derived Data for

Plutonium Compound Solubility in the $\mathrm{NaOH} / \mathrm{Na}_{2} \mathrm{CO}_{3}$ Aqueous System

\begin{tabular}{|c|c|c|c|c|c|c|c|}
\hline $\begin{array}{c}{[\mathrm{NaOH}],} \\
\mathrm{M}\end{array}$ & $\begin{array}{c}{\left[\mathrm{Na}_{2} \mathrm{CO}_{3}\right],} \\
\mathrm{M}\end{array}$ & $\begin{array}{c}a_{\mathrm{NaOH}}, \\
\mathrm{m}\end{array}$ & $\frac{a_{\mathrm{Na} 2 \mathrm{CO} 3}}{\mathrm{~m}}$ & $\begin{array}{c}\log [\mathrm{Pu}]_{t} \\
\mathrm{~m}\end{array}$ & $\begin{array}{c}\log [\mathrm{PuOH}] \\
\mathbf{m}\end{array}$ & $\begin{array}{c}\log \left[\mathrm{PuCO}_{3}\right] \\
\mathrm{m}\end{array}$ & $\begin{array}{c}\log \left(\mathrm{a}_{\mathrm{Na} 2 \mathrm{CO} 3}\right) \\
\mathbf{m}\end{array}$ \\
\hline 2.90 & 0.701 & 2.39 & 0.416 & -6.124 & -6.788 & -6.230 & -0.381 \\
\hline 2.95 & 0.512 & 2.38 & 0.310 & -6.488 & -6.791 & -6.787 & -0.509 \\
\hline 2.95 & 0.912 & 2.45 & 0.522 & -6.058 & -6.766 & -6.153 & -0.282 \\
\hline 2.95 & 1.050 & 2.58 & 0.610 & -5.940 & -6.721 & -6.019 & -0.215 \\
\hline 2.96 & 0.261 & 2.46 & 0.172 & -6.377 & -6.763 & -6.607 & -0.764 \\
\hline 3.24 & 0.255 & 2.81 & 0.172 & -6.424 & -6.647 & -6.820 & -0.764 \\
\hline 3.47 & 0.515 & 3.18 & 0.335 & -6.157 & -6.540 & -6.389 & -0.475 \\
\hline 3.47 & 0.783 & 3.32 & 0.496 & -6.061 & -6.503 & -6.256 & -0.305 \\
\hline 3.94 & 0.515 & 3.92 & 0.347 & -5.975 & -6.359 & -6.207 & -0.460 \\
\hline 3.94 & 0.771 & 4.02 & 0.500 & -5.567 & -6.337 & -5.648 & -0.301 \\
\hline 3.99 & 1.060 & 4.29 & 0.673 & -5.421 & -6.280 & -5.486 & -0.172 \\
\hline 4.00 & 0.260 & 3.88 & 0.185 & -6.192 & -6.367 & -6.670 & -0.733 \\
\hline 4.43 & 0.513 & 4.85 & 0.362 & -5.745 & -6.174 & -5.947 & -0.441 \\
\hline 4.52 & 0.766 & 5.29 & 0.531 & -5.358 & -6.099 & -5.445 & -0.275 \\
\hline 4.69 & 1.060 & 5.76 & 0.712 & -5.118 & -6.025 & -5.175 & -0.148 \\
\hline 4.75 & 0.765 & 5.57 & 0.527 & -5.421 & -6.054 & -5.536 & -0.278 \\
\hline 4.80 & 0.484 & 5.61 & 0.354 & -5.674 & -6.048 & -5.913 & -0.451 \\
\hline 4.85 & 0.250 & 5.57 & 0.194 & -5.983 & -6.054 & -6.805 & -0.712 \\
\hline 4.89 & 1.050 & 6.72 & 0.852 & -4.779 & -5.891 & -4.814 & -0.070 \\
\hline 4.94 & 0.257 & 5.78 & 0.201 & -5.816 & -6.022 & -6.239 & -0.697 \\
\hline
\end{tabular}


WHC-SP-1156

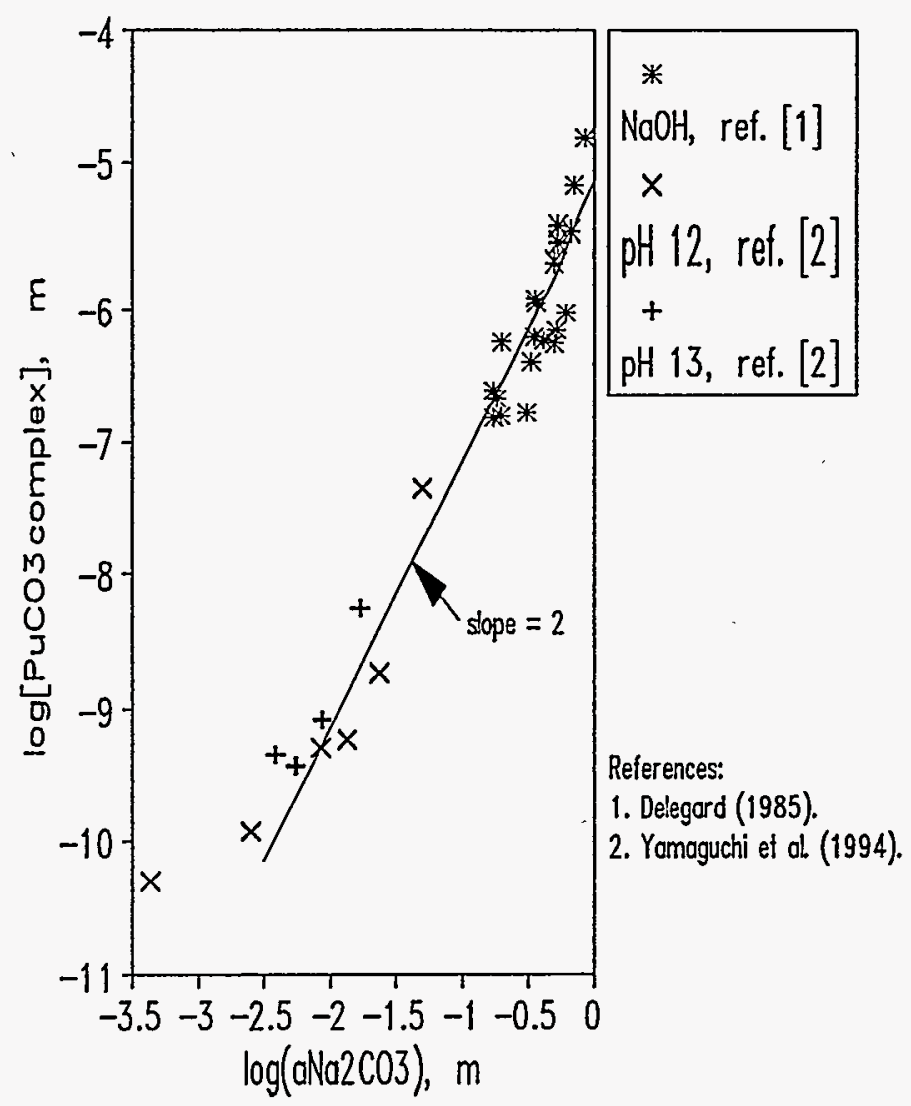

Figure 6. Effect of Carbonate on Plutonium Compound Solubility 
WHC-SP-1156

\subsection{ACKNOWLEDGEMENTS}

The author is deeply indebted to Bette Lauzon, Rebecca Conner, Gene Wattenburger, Penny Gregory, and Sylvia Harlow of Multimedia Services for their tireless and painstaking work in preparing the technical literature review (Peretrukhin et al. 1995) for publication. The author also thanks Judy Watts, Jeff Chenault, and especially Wayne Edmonson for their able assistance in the laboratory. 


\section{WHC-SP-1156}

\subsection{REFERENCES}

Bourges, J., 1972, "Preparation et Identification du Plutonium a l'Etat d'Oxydation-V en Mileau Basique," Radiochem. Radioanal. Letters 12, 111-116.

Cohen, D., and S. Fried, 1969, "Some Observations on the Chemistry of Neptunium in Basic Solution," Inorg. Nucl. Chem. Letters 5, 653-663.

Delegard, C. H., 1985, Solubility of $\mathrm{PuO}_{2} \cdot \mathrm{xH}_{2} \mathrm{O}$ in Alkaline Hanford High-Level Waste Solution, RHO-RE-SA-75 P, Rockwell Hanford Operations, Richland, Washington. Also, Radiochimica Acta 41, 11-21, (1987), same title and author.

Delegard, C. H., T. D. Elcan, and B. E. Hey, 1994a, Chemistry of Application of Calcination/Dissolution to the Hanford Tank Waste Inventory, WHC-EP-0766, Westinghouse Hanford Company, Richland, Washington.

Delegard, C. H., R. F. Creed, and D. W. Hendrickson (Westinghouse Hanford Company) and D. F. McLaughlin (Westinghouse Science and Technology Center) 1994b, Calcination/Dissolution Process Development 1994, WHC-SP-1093, Rev. 0, Westinghouse Hanford Company, Richland, Washington.

Delegard, C. H., 1995, Chemistry of Proposed Calcination/Dissolution Processing of Hanford Site Tank Wastes, WHC-EP-0832, Westinghouse Hanford Company, Richland, Washington.

Felmy, A. R., D. Rai, and R. W. Fulton, 1994, The Solubility of $\mathrm{Cr}(\mathrm{OH})_{3}(\mathrm{am})$ in Concentrated $\mathrm{NaOH}$ and $\mathrm{NaOH}-\mathrm{NaNO}_{3}$ Solutions, PNL-SA-24027, Battelle Pacific Northwest Laboratories, Richland, Washington.

Goheen, R. S. (Battelle Pacific Northwest Laboratories), P. R. Taylor, S. A. Pirzada, and M. Manrique (College of Mines, University of Idaho), 1995, Thermal Reconstitution of a Hanford Tank Waste Simulant via Plasma Calcination, TWRSPP-95-003, Battelle Pacific Northwest Laboratory, Richland, Washington.

Herting, D. L., D. B. Bechtold, B. E. Hey, B. D. Keele, L. Jensen, and T. L. Welsh, 1992, Laboratory Characterization of Samples Taken in December 1991 (Window E) from Hanford Waste Tank 241-SY-101, WHC-SD-DTR-026, Rev. 0, Westinghouse Hanford Company, Richland, Washington.

Hudson, L. K., 1987, "Alumina Production," in Production of Aluminium and Alumina, A. R. Burkin, (ed.), Critical Reports on Applied Chemistry, Vol. 20, John Wiley \& Sons, Inc., Chichester, UK. 


\section{WHC-SP-1156}

Musikas, C., 1976, "Contribution to the Study of U(V) Ions and Pentavalent Transuranics in Aqueous Solution," in Proceedings of the Moscow Symposium on the Chemistry of the Transuranium Elements, V. I. Spitsyn and J. J. Katz, eds., Supplement to the J. Inorganic and Nuclear Chemistry, 171-177, Pergamon Press, Oxford, UK.

Peretrukhin, V. F. (Institute of Physical Chemistry, Russian Academy of Sciences) and C. H. Delegard (Westinghouse Hanford Company), 1995, Studies of the Chemistry of Transuranium Elements and Technetium at the Institute of Physical Chemistry, Russian Academy of Sciences, Supported by the U. S. Department of Energy, WHC-SA-2588-FP, Westinghouse Hanford Company, Richland, Washington.

Peretrukhin, V. F., V. P. Shilov, and A. K. Pikaev, 1995, Alkaline Chemistry of Transuranium Elements and Technetium and the Treatment of Alkaline Radioactive Wastes, WHC-EP-0817, Westinghouse Hanford Company, Richland, Washington.

Yamaguchi, T., Y. Sakamoto, and T. Ohnuki, 1994, "Effect of the Complexation on Solubility of Pu(IV) in Aqueous Carbonate System," Radiochimica Acta 66/67, 9-14. 


\section{DISTRIBUTION}

\section{Number of Copies}

\section{OFFSITE}

$1 \quad$ United States Department of Energy

12800 Middlebrook Road

Trevion II Building

Germantown, Md 20874

T. Fryberger

\section{ONSITE}

1 MACTEC

D. J. Swanberg

2 Pacific Northwest Laboratory

W. L. Kuhn (2)

3 U.S. Department of Energy

$\underline{\text { Richland Field Office }}$
B. A. Mauss
S. N. Runyon
D. E. Trader

$\mathrm{K} 8-50$

$\mathrm{K} 8-50$

$\mathrm{K} 8-50$

12 Westinghouse Hanford Company
R. A. Bechtold
J. D. Berger
K. D. Boomer
C. H. Delegard (3)
D. W. Hendrickson
J. R. Jewett
S. L. Lambert
OSTI (2)
Central Files

L0-18

L0-18

H5-49

T6-09

L5-31

T6-09

H5-27

L8-07

L8-04 